\title{
Tribological Behavior of Silicon Carbide Ceramics - A Review
}

\author{
Sandan Kumar Sharma, B. Venkata Manoj Kumar ${ }^{\dagger}$ and Young-Wook Kim* \\ Department of Metallurgical and Materials Engineering, Indian Institute of Technology (IIT) Roorkee, Roorkee 247667, India \\ *Functional Ceramics Laboratory, Department of Materials Science and Engineering, the University of Seoul, Seoul 02504, Korea
}

(Received August 10, 2016; Accepted September 9, 2016)

\begin{abstract}
A comprehensive review on sliding and solid particle erosion wear characteristics of silicon carbide (SiC) ceramics and $\mathrm{SiC}$ composites is provided. Sliding or erosion wear behavior of ceramics is dependent on various material characteristics as well as test parameters. Effects of microstructural and mechanical properties of SiC ceramics are particularly focused to understand tribological performance of $\mathrm{SiC}$ ceramics. Results obtained between varieties of pairs of $\mathrm{SiC}$ ceramics indicate complexity in understanding dominant mechanisms of material removal. Wear mechanisms during sliding are mainly divided in two groups as mechanical and tribochemical. In solid particle erosion conditions, wear mechanisms of SiC ceramics are explained by elastic-plastic deformation controlled micro-fracture on the surface followed by radial-lateral crack propagation beneath the plastic zone.
\end{abstract}

Key words : Silicon carbide, Sliding wear, Erosion wear, Microstructure, Wear mechanisms

\section{Introduction}

$\mathrm{S}$ ilicon carbide, a well-recognized structural ceramic material has been used in industries for a long period owing to its unique combination of properties such as high hardness, high modulus, high temperature strength, good oxidation resistance, excellent wear resistance, good thermal shock resistance, and high thermal conductivity. ${ }^{1-3)}$ The fundamental structure of covalently bonded silicon carbide is a coordinated tetrahedron, either $\mathrm{SiC}_{4}$ or $\mathrm{CSi}_{4}$. Although a great variety of $\mathrm{SiC}$ polytypes is known, important are cubic polytype referred as $\beta$-SiC, and non-cubic structures (hexagonal or rombohedral) as $\alpha-\mathrm{SiC}^{4-10)}$ The strong covalent bond and extremely low self-diffusion coefficient $\left(10^{-13}-10^{-14} \mathrm{~cm}^{2} /\right.$ sec) pose difficulties in densification of $\mathrm{SiC}$ powders at lower temperatures. The densification is possible only at extremely high pressure (30-100 $\mathrm{MPa}$ ) and temperatures exceeding $2100^{\circ} \mathrm{C}$. In order to achieve high density at lower temperatures and pressures, use of sintering aids is necessary. ${ }^{11-22)}$

Metal oxides, Al-B-C, AlN-metal oxides as sintering additives during liquid-phase sintering tailor the microstructure and improve fracture toughness of $\mathrm{SiC}$ ceramics. ${ }^{2,16,18,21-22)}$ The platelet-reinforced microstructures exhibit enhanced toughness due to the combination of intergranular crack mode, introduced by the glassy grain boundary phase, and energy dissipating processes in the crack wake. ${ }^{23)}$ Sintering additive composition also affect the crystallinity of grain boundary phase of SiC ceramics. Further details on sinter-

${ }^{\dagger}$ Corresponding author : B. Venkata Manoj Kumar E-mail : manojfmt@iitr.ac.in

Tel : +91-1332-285420 Fax : +91-1332-285243 ing and microstructure can be found elsewhere. ${ }^{15,17-19,24-28)}$

Owing to attractive properties, liquid phase sintered silicon carbide (LPS-SiC) ceramics are preferred for several tribological and structural applications such as turbine parts, heat exchanger tubes, mechanical seals, bearings, cylinder liners, burner parts in fluidized bed combustion system, bullet proof vests, cutting tools etc. ${ }^{28-36)}$ A thorough understanding on tribological behavior of $\mathrm{SiC}$ ceramics is required for their successful application as triboelements. Accordingly, extensive research has been carried out towards estimating tribological potential of $\mathrm{Si}$ and $\mathrm{SiC}$-based composites. ${ }^{37-50)}$ Available literature on tribology of $\mathrm{SiC}$ ceramics can be broadly divided into two categories: sliding and erosion.

Based on the conditions of sliding and characteristics of $\mathrm{SiC}$ and $\mathrm{SiC}$ composites, the coefficient of friction (COF) in unlubricated sliding studies reported to be varied in the wide range of $0.2-0.8$, which decreased up to 0.02 in lubricating media like water, paraffin oil etc. ${ }^{48-57)}$ Wear rates in sliding conditions varied in the order of $10^{-7}-10^{-4} \mathrm{~mm}^{3}$ / N.m..$^{38-44,58-59)}$ Erosion of $\mathrm{SiC}$ ceramics is mainly studied in solid particle erosion conditions, while that in cavitation conditions ${ }^{60)}$ is limited. Solid particle erosion of $\mathrm{SiC}$ and $\mathrm{SiC}$ based composites is reported to occur generally by brittle fracture as a result of lateral and radial cracking. Erosion rate ranges from $10^{-1}$ to $10^{3} \mathrm{~mm}^{3} / \mathrm{kg}$ based on erosion parameters, and microstructural and mechanical characteristics of SiC ceramics. ${ }^{61-67)}$ The complex tribological behavior of $\mathrm{SiC}$ ceramics and their composites in sliding and solid particle erosion conditions was mostly explained by several material removal mechanisms such as mechanical fracture, chipping, plastic deformation, ploughing, and/or formation and removal of tribooxide layer. ${ }^{39-48,68)}$

Considering the importance of the influence of microstruc- 
ture and mechanical properties of SiC ceramics in different wear conditions, a comprehensive understanding on sliding and solid particle erosion wear behavior of $\mathrm{SiC}$ ceramics and composites is provided in the present review. Effects of material parameters on wear behavior are extensively reviewed. The other important part of the review is focused on understanding dominant mechanisms of material removal as function of microstructure and mechanical characteristics of $\mathrm{SiC}$ ceramics in the sliding and erosion conditions.

\section{Sliding Wear of SiC Ceramics}

Sliding wear of $\mathrm{SiC}$ ceramics are reported mainly using ball-on-disk or pin-on-disk tribometer. SiC ceramics showed complex behavior of wear influenced by sliding test, material or environmental parameters in lubricated/unlubricated sliding conditions. ${ }^{39-54,68)}$ In this section effect of microstructure and mechanical characteristics on sliding wear of SiC ceramics are separately discussed. This is followed by detailed understanding on dominant wear mechanism of SiC ceramics in sliding conditions.

\subsection{Effect of microstructure}

Lopez et $a l .{ }^{48)}$ studied the sliding wear behavior of LPS$\mathrm{SiC}$ ceramics with different microstructures like elongated $\mathrm{SiC}$ grains (in situ toughened LPS $\mathrm{SiC}$ ), coarse equiaxed $\mathrm{SiC}$ grains, and fine equiaxed $\mathrm{SiC}$ grains. Sliding wear resistance of elongated grain $\mathrm{SiC}$ ceramics was better than that of equiaxed $\mathrm{SiC}$ ceramics owing to a hard interlocking network of in situ toughened LPS SiC grains (see Fig. 1). The isolated nature of the yttrium aluminum garnet (YAG) second phase also played a role in enhancing wear resistance of in situ toughened LPS-SiC. This was in contrast to the equiaxed $\mathrm{SiC}$ ceramics, where the grains were embedded within
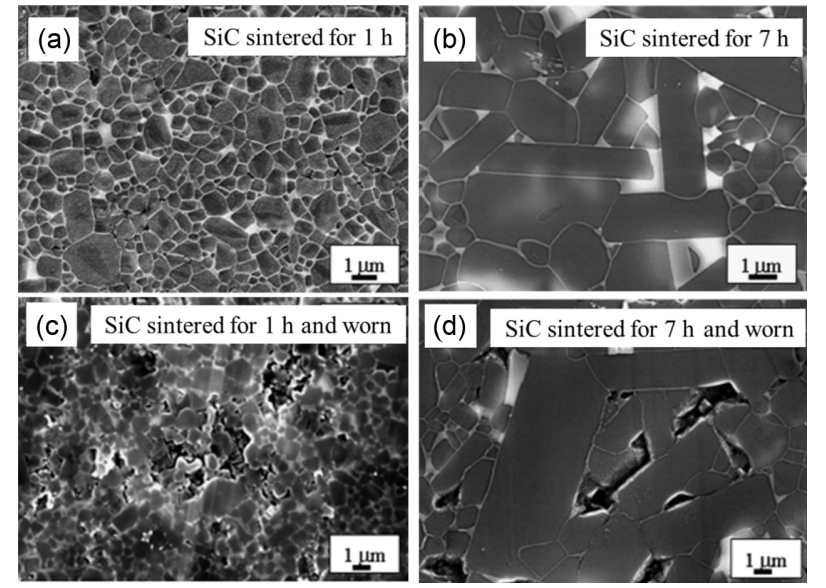

Fig. 1. Typical SEM images of $\operatorname{SiC}$ ceramics $(a, b)$ unworn and (c, d) after sliding against $\mathrm{Si}_{3} \mathrm{~N}_{4}$ ball. Note the presence of elongated grains in (b) and equiaxed grains in (a), and comparatively less wear in (d) than in (c). Other conditions of sintering and sliding wear can be found in. ${ }^{48}$ a continuous YAG phase matrix.

In sliding of $\mathrm{SiC}$ ceramics prepared with $\mathrm{YAG}\left(\mathrm{Y}_{2} \mathrm{O}_{3}: \mathrm{Al}_{2} \mathrm{O}_{3}=\right.$ $3: 5$ ), Lopez et $a l^{50)}$ suggested reduced content of the intergranular phase or grain size for improvement in wear resistance of LPS $\alpha$-SiC ceramics. Reduced content of intergranular phase and the grain refinement resulted in reduction of rate of transition from deformation-controlled wear to fracture-controlled wear and hence in wear loss.

A simple model by Lawn et $a l .{ }^{69)}$ provided a framework for estimating the sliding wear properties in polycrystalline ceramics. The proposed model states that the plastic-deformation damage accumulates within the grains during deformation-controlled wear. This damage is in the form of dislocation pile-ups, confirmed using transmission electron microscopy. ${ }^{69-71)}$

It was earlier concluded that $\mathrm{SiC}$ ceramics sintered using $3 \mathrm{wt} \% \mathrm{AlN}-\mathrm{Y}_{2} \mathrm{O}_{3}$ (SCY3) additives revealed mostly large equiaxed grains with amorphous grain boundary phase, while $\mathrm{SiC}$ ceramics prepared using 3 wt\% $\mathrm{AlN}-\mathrm{Sc}_{2} \mathrm{O}_{3}$ (SCSc3) additives exhibited duplex microstructure of elongated and fine equiaxed grains with clean grain boundary phase (see Figs. 2(a) and (b)). SiC ceramics prepared using 3 $\mathrm{wt} \% \mathrm{AlN}-\mathrm{Sc}_{2} \mathrm{O}_{3}$ additives resulted $\sim 18 \%$ less wear at $13 \mathrm{~N}$ load. Worn surfaces of SCY3 and SCSc3 are shown in Figs. 2(c), and (d), respectively. ${ }^{2)}$

Murthy et al. ${ }^{72)}$ observed that SiC ceramics doped with different $\mathrm{p}$-type $(\mathrm{Al}, \mathrm{Mg})$ or $\mathrm{n}$-type $(\mathrm{P})$ doping elements had influence on the wear behavior in two ways: (i) by directly affecting thermodynamics of tribochemical reactions or (ii) by modified frequency of grain boundaries having same orientation angle and change in the kinetics of tribochemical reactions. It was found that doping elements partly made a sloid solution with $\mathrm{SiC}$ and rest were segregated along grain boundaries. Segregated $\mathrm{Al}$ reduced solubility of silica largely in water, whereas $\mathrm{P}$ and $\mathrm{Mg}$ reduced solubility to a lesser extent. ${ }^{73)}$ Kinetics of formation of hydrated silica var-
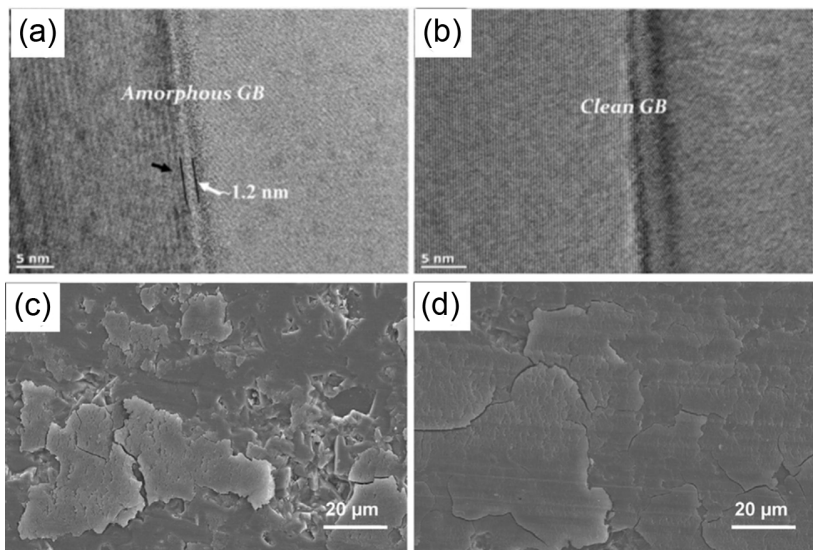

Fig. 2. TEM images of $\mathrm{SiC}$ ceramics revealing (a) amorphous grain boundary in $\mathrm{SiC}$ ceramics prepared with $3 \mathrm{wt} \%\left(\mathrm{AlN}-\mathrm{Y}_{2} \mathrm{O}_{3}\right)$ additive (b) clean grain boundary in $\mathrm{SiC}$ ceramics prepared with 3 wt\% $\left(\mathrm{AlN}_{-} \mathrm{Sc}_{2} \mathrm{O}_{3}\right)$. Worn surfaces of (a) and (b) are respectively shown in (c) and (d). ${ }^{2}$ 
ied with solubility and hence led to change in frictional characteristics of $\mathrm{SiC}$ ceramics.

For improvements in the sliding-wear resistance of pressureless LPS-SiC under diesel lubrication, Ciudad et $a l{ }^{74)}$ suggested (i) reduction in intergranular phase (second phase) content, and (ii) decrease in grain size or increase in grain aspect ratio. They reported that $\mathrm{SiC}$ ceramics with similar grain size (of $1.1 \mu \mathrm{m}$ ) but having large amount of second phase exhibited high wear. Second phase led to decrease in hardness and increase in wear.

Ortiz et $a l .{ }^{54)}$ proposed a colloidal processing route to produce dense SiC ceramics via pressureless liquid-phase sintering (PLPS). In addition to uniform mixing, the colloidal processing route resulted in a nano film of $\sim 5 \mathrm{~nm}$ thickness on the surface of $\mathrm{SiC}$ particles. Compared to conventional mixing and sintering, complete densification achieved in shorter sintering time and minimum defects found in ceramics sintered using colloidal processed powders. The time required for the transition from mild to severe wear was more than double for $\mathrm{SiC}$ ceramics prepared by colloidal processing as compared to that for the $\mathrm{SiC}$ ceramics prepared by conventional processing. It was advocated that, though the microstructures were similar in terms of the size and morphology of grains for ceramics prepared through both processing routes, the clear interphase with fully dense structure led to a superior wear resistance.

Zhou et $a l .{ }^{75)}$ reported that silicon carbide-graphite (SiC-C) composites exhibited lower coefficients of friction during sliding than the monolithic SiC. The flake like graphite particles present in SiC-C composites (see Fig. 3) were expected to provide solid lubrication with easy shear during sliding. However, in the high contact stress condition (pin-on-disk tests), wear rates enhanced sharply from 0.38 to $3.90 \times 10^{-6}$ $\mathrm{mm}^{3} / \mathrm{N} . \mathrm{m}$ for SiC-C composites which was attributed to the fracture of graphite flakes despite lowered coefficients of
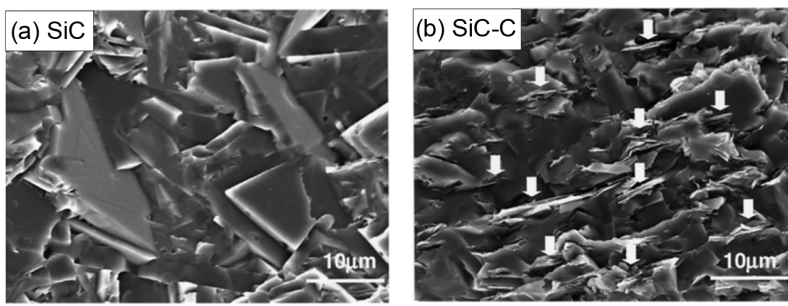

Fig. 3. Fracture surfaces of (a) $\mathrm{SiC}$ and (b) $\mathrm{SiC}-20$ vol\% graphite (SiC-C) composite. The graphite particles in $\mathrm{SiC}-\mathrm{C}$ composite remain flake like, as indicated by the arrows. ${ }^{75)}$ friction when compared to low contact stress condition (block-on-ring test) (See Table 1).

In other research, ${ }^{76)} \mathrm{SiC}$ ceramics with $0,10,30$ or 50 wt\% $\mathrm{WC}$ were slid against $\mathrm{SiC}$ ball. WC reinforcement led to a decrease in size of equiaxed grains from $835 \mu \mathrm{m}$ to $578 \mu \mathrm{m}$ of $\mathrm{SiC}$ ceramics and resulted improvement in wear resistance from $1.3 \times 10^{-5} \mathrm{~mm}^{3} / \mathrm{N}$.m to $4 \times 10^{-6} \mathrm{~mm}^{3} / \mathrm{N}$.m (see Fig. 4).

\subsection{Effect of mechanical properties}

Mechanical properties such as fracture toughness, hardness, and elastic modulus have influence on sliding wear characteristics of $\mathrm{SiC}$ ceramics. Hardness and fracture toughness of $\mathrm{SiC}$ ceramics are reported to generally range from $16 \mathrm{GPa}$ to $27 \mathrm{GPa}$, and $2.3 \mathrm{MPa} \cdot \mathrm{m}^{1 / 2}$ to $8.3 \mathrm{MPa} \cdot \mathrm{m}^{1 / 2}$, respectively based on types of sintering/additives, microstructure etc. ${ }^{49,51,77-80)}$ Particularly, the influence of hardness and fracture toughness on friction and wear behavior was debated in most of the reports.

A sharp indenter model and a blunt indenter model were proposed to estimate the sliding wear broadly in the tribocontact of brittle materials in absence of any layer formation. According to Marshall et $a l^{81)}$ for the tribocontact of sharp indenters, wear in brittle materials occurs due to the formation and propagation of lateral cracks. For a given applied load $(P)$, total sliding distance $(S)$, hardness $(H)$, fracture toughness $\left(K_{I C}\right)$ and elastic modulus $(E)$, wear vol-

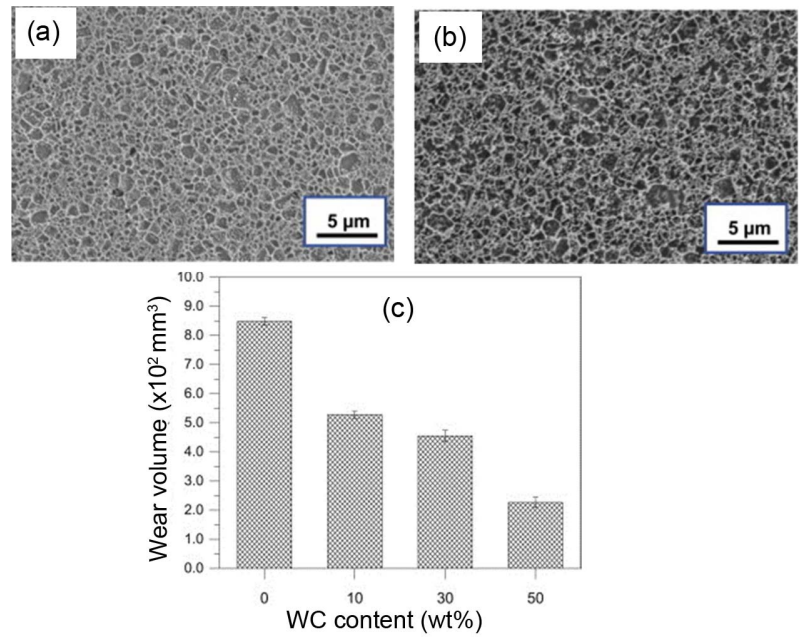

Fig. 4. Etched surfaces of $\mathrm{SiC}$ ceramics prepared with (a) $10 \% \mathrm{WC}$, and (b) $50 \% \mathrm{WC}^{61)}$ Sliding wear volume as function of WC content is shown in (c). ${ }^{76)}$

Table 1. Friction and Wear Data for SiC-C Ceramics for Different Triboconfigurations ${ }^{75)}$

\begin{tabular}{ccccc}
\hline \multirow{2}{*}{ Specimen } & \multicolumn{2}{c}{ Average coefficient of friction } & \multicolumn{2}{c}{ Wear rate $\left(\mathrm{X} 10^{-6} \mathrm{~mm}^{3} / \mathrm{N} \cdot \mathrm{m}\right)$} \\
\cline { 2 - 5 } & Block-on-ring & Pin-on-disk & $\begin{array}{c}\text { Block specimen } \\
\text { in block-on-ring test }\end{array}$ & $\begin{array}{c}\text { Pin specimen } \\
\text { in pin-on-disk test }\end{array}$ \\
\hline SiC & 0.64 & 0.28 & 4.60 & 0.38 \\
SiC- 10 vol. \%C & 0.55 & 0.15 & 3.20 & 2.90 \\
SiC- 20 vol. \%C & 0.49 & 0.14 & 6.20 & 2.30 \\
\hline
\end{tabular}


ume of the brittle solid $\left(V_{S}\right)$ can be assessed using the following equation: ${ }^{81)}$

$$
V_{S}=\alpha \frac{P^{9 / 8}}{K_{I C}^{1 / 2} H^{5 / 8}}\left(\frac{E}{H}\right)^{4 / 5} S
$$

where $\alpha$ is a material constant. In case of blunt indenter pressed against a brittle solid, surface ring cracks are generated, which propagate towards downwards with repeated sliding contact and develop conical cracks to cause pull-out of material. ${ }^{82)}$ Following Hertzian analysis, when there was no tribochemical layer formation, Tewari et al. estimated wear volume $\left(\mathrm{V}_{\mathrm{B}}\right)$ for brittle materials in ball-on-disk fretting wear contacts as per the following relation. ${ }^{83)}$

$$
V_{B}=\frac{2 \pi \beta^{2} s}{3}\left(\frac{3 P R}{4 E}\right)^{2 / 3} \sqrt{\left(\left(\frac{4 \chi^{2} E P}{3 \beta^{3} K_{I C}^{2} R}\right)-1\right)}
$$

where $\mathrm{R}$ is radius of the ball, $x$ and $\beta$ are constants, and $s$ is the stroke length in fretting contact.

$\mathrm{SiC}$ ceramics sintered with small amount $(0.2 \mathrm{wt} \%)$ of $\mathrm{Y}_{2} \mathrm{O}_{3}$ additives attributed to high strength $(561 \mathrm{MPa})$ and high hardness $(27.7 \mathrm{GPa})$ than the $\mathrm{SiC}$ ceramics sintered with large amount (3 wt\%) of $\mathrm{Y}_{2} \mathrm{O}_{3}$ additives (542 $\mathrm{MPa}$ and $26.1 \mathrm{GPa}$ ), and exhibited superior wear resistance. ${ }^{84)} \mathrm{Li}$ et $a l .^{85)}$ found that toughened SiC prepared by hot pressing showed high hardness and fracture toughness compared to the $\mathrm{SiC}$ ceramics prepared through pressureless sintering or reaction sintering. The same trend reflected for resistance against friction and wear in water-lubrication conditions against $\mathrm{SiC}$ counterbody. Lopez et al. ${ }^{51)}$ reported that elongated-grain LPS SiC, despite having lower hardness, showed almost a half of the wear rate than that obtained for equiaxed-grain LPS SiC, and reflected less extent of dislocation plasticity. They also differentiated the extent of wear as mild wear dominated by hardness and severe wear dominated by fracture toughness of LPS SiC ceramics. Kovalcikova et al. ${ }^{86)}$ used brittleness index $\left(\mathrm{H} / \mathrm{K}_{1 \mathrm{c}}\right)$ of material for qualitative estimation of specific wear rate of $\mathrm{SiC}$ against $\mathrm{Si}_{3} \mathrm{~N}_{4}$. They observed that brittleness index had dominant role in the wear response. Their results showed that resistance to wear increases with increased index number. In other study on SiC-WC composites ${ }^{76)}$ the influence of hardness and fracture toughness on the sliding wear of the SiCWC composites was realized. The maximum hardness of $26.3 \mathrm{GPa}$ for $\mathrm{SiC}$ reinforced with $30 \mathrm{wt} \% \mathrm{WC}$ particles resulted in homogeneous dispersion of WC particles in the $\mathrm{SiC}$ matrix, whereas, a higher fracture toughness obtained due to crack deflection and bridging by a large amount (30 or $50 \mathrm{wt} \%$ ) of WC particles. ${ }^{61)}$ The minimum material removal for $\mathrm{SiC}$ ceramics sintered with $50 \mathrm{wt} \% \mathrm{WC}$ attributed to the maximum fracture toughness. Thus, fracture toughness appeared to carry important role than hardness towards estimating the extent of sliding wear for the investigated SiC-WC composites.

Llorente et al. ${ }^{79)}$ studied tribological nature of $\mathrm{SiC}$ compos- ites prepared with different types and amounts of graphenebased sources. They demonstrated the importance of graphene fillers in resisting wear during sliding. According to them, the choice of the most suitable amount and type of graphene in $\mathrm{SiC}$ composites for tribological and mechanical applications is dependent on their specific working requirements. SiC composites with 20 vol\% graphene nanoplatelets (GNPs) clearly exhibited $72 \%$ higher wear resistance compare to the monolithic SiC (see Fig. 5). It was demonstrated that an optimum combination of mechanical properties is required to provide the best wear resistance for $\mathrm{SiC}$ ceramics.

Amirthan et al. ${ }^{87)}$ studied the reciprocating sliding friction and wear characteristics of cotton fabric/teak wood/jute fiber based Si/SiC. Among the investigated composites, fine teak wood and cotton based samples exhibited less COF of 0.25 and 0.23 and less wear rate of $3.0 \times 10^{-6}$ and $1.24 \times 10^{-6}$ $\mathrm{mm}^{3} / \mathrm{N}$.m respectively in dry sliding condition. This was attributed to the carbon film formation that acted as lubricating media on the wear track. Alumina particles, generated as debris from alumina counterbody balls acted as third body for harder surfaces. Third body abrasion of the surfaces led to high wear of harder chemical vapor infiltration treated cotton based sample. On the other hand, porous nature of the coarse wood particle and jute fiber based sample surfaces exhibited high wear.

Candelario et $a l{ }^{88)}$ introduced graphite nanodispersoids into the microstructure of a fine-grained LPS SiC ceramics fabricated by spark plasma sintering and studied the sliding wear characteristics in regular diesel fuel (viscosity of $\sim 3.8 \mathrm{cSt}$ ) lubricating conditions. Addition of graphite nanodispersoids was detrimental to mild wear and transition from mild to severe wear occurred in shorter time due to softer graphite particles. On other side, the addition of graphite nanodispersoids led to increased fracture toughness and provided external lubrication after grain pull-out. This was resulted in effectively decreasing wear damage for

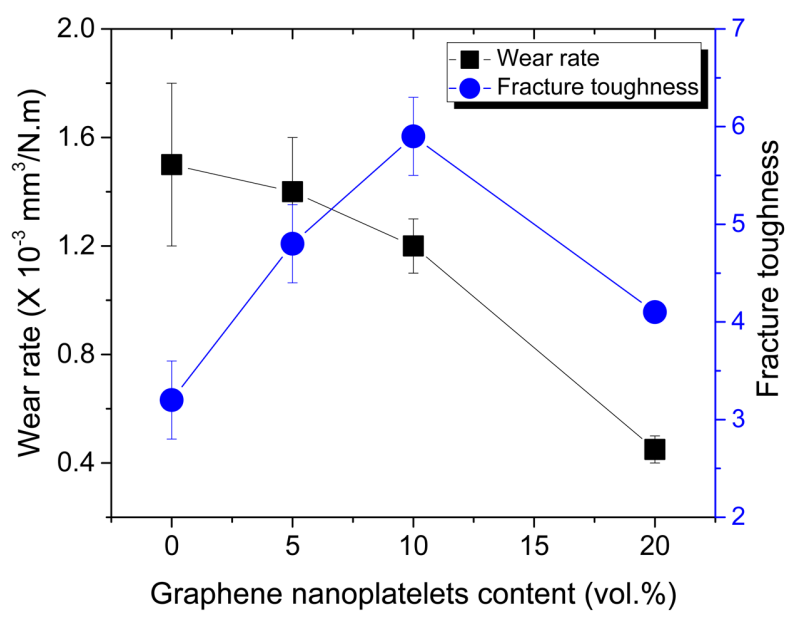

Fig. 5. The wear rate and fracture toughness of SiC- graphene nanoplatelets composites as function of content of graphene nanoplatelets. ${ }^{79}$ 
Table 2. Summary of Major Findings from Sliding Wear Studies of SiC Based Ceramics

\begin{tabular}{|c|c|c|c|c|c|}
\hline \multirow{2}{*}{$\begin{array}{l}\text { Materials } \\
\text { (SiC based ceram- } \\
\text { ics/ Counter body) }\end{array}$} & \multicolumn{3}{|c|}{ Sliding test parameters } & \multirow[b]{2}{*}{ Major Findings } & \multirow[b]{2}{*}{ References } \\
\hline & Speed & Load & $\begin{array}{c}\text { Environment } \\
\text { or Lubrication }\end{array}$ & & \\
\hline $\mathrm{SiC}$ pin/SiC disk & $2 \mathrm{~mm} / \mathrm{s}$ & $\begin{array}{l}5,30,50 \\
100 \mathrm{~N}\end{array}$ & $\begin{array}{l}50 \pm 2 \% \mathrm{RH} \\
\text { and } 19 \pm 2^{0} \mathrm{C}\end{array}$ & $\begin{array}{l}\text { A hydrated silicium oxide film forms and } \\
\text { functions as a lubricating film to reduce } \\
\text { friction and wear. }\end{array}$ & 89) \\
\hline $\mathrm{SiC}$ ball/SiC disk & $\begin{array}{c}10 \mathrm{~mm} / \mathrm{s} \\
1 \mathrm{~m} / \mathrm{s}\end{array}$ & $\begin{array}{c}250 \mathrm{mN} \\
1 \mathrm{~N}\end{array}$ & $\begin{array}{l}\text { vacuum } \\
\text { Air }\end{array}$ & $\begin{array}{l}\text { In vacuum, the transition from severe to } \\
\text { mild wear was connected with smoothening } \\
\text { of surface roughness. }\end{array}$ & 41) \\
\hline $\begin{array}{l}\mathrm{Si}_{3} \mathrm{~N}_{4} \text { ball/LPS-SiC } \\
\text { disks }\end{array}$ & $\begin{array}{l}\sim 0.04 \mathrm{~m} / \mathrm{s} \text { to } \\
\sim 0.01 \mathrm{~m} / \mathrm{s}\end{array}$ & $\begin{array}{l}240 \mathrm{~N} \\
\text { to } 100 \mathrm{~N}\end{array}$ & $\begin{array}{c}\text { Diesel } \\
\text { (viscosity } \sim 3.8 \mathrm{cst} \text { ) }\end{array}$ & $\begin{array}{l}\text { Resistance to sliding decreases with increas- } \\
\text { ing contact load and sliding speed. }\end{array}$ & 74) \\
\hline $\begin{array}{l}\mathrm{Si}_{3} \mathrm{~N}_{4} \text { ball/LPS- } \alpha- \\
\mathrm{SiC} \text { disk }\end{array}$ & $\sim 0.04 \mathrm{~m} / \mathrm{s}$ & $70 \mathrm{~N}$ & $\begin{array}{l}\text { Paraffin oil (viscosity } \\
\qquad 34 \text { cst) }\end{array}$ & $\begin{array}{l}\text { The superior sliding wear resistance of } \\
\text { low-cost in situ toughened SiC ceramic was } \\
\text { most likely due to the formation of inter- } \\
\text { locking networks of elongated SiC grains. }\end{array}$ & $50)$ \\
\hline $\begin{array}{l}\mathrm{SiC} \text { ball/ } / \mathrm{SiC}-3 \mathrm{wt} \% \\
\left(\mathrm{AlN}-\mathrm{Sc}_{2} \mathrm{O}_{3} \text { or } \mathrm{AlN}-\right. \\
\left.\mathrm{Y}_{2} \mathrm{O}_{3}\right) \text { disk }\end{array}$ & $0.21 \mathrm{~m} / \mathrm{s}$ & $\begin{array}{l}1 \mathrm{~N}, 6 \mathrm{~N} \text { or } \\
13 \mathrm{~N}\end{array}$ & $\begin{array}{c}20-580^{\circ} \mathrm{C} \text { and } 50- \\
10 \% \mathrm{RH}\end{array}$ & $\begin{array}{l}\text { SiC ceramics sintered with } 3 \text { wt\% } \\
\text { AlN- } \mathrm{Sc}_{2} \mathrm{O}_{3} \text { additives exhibited less wear. } \\
\text { Surface grooving and microcracking } \\
\text { occurred at low load }(1 \mathrm{~N}) \text {. Tribochemical } \\
\text { wear was dominant at } 6 \text { and } 13 \mathrm{~N} \text { loads for } \\
\text { all the ceramics. }\end{array}$ & 2) \\
\hline $\begin{array}{l}\alpha \text {-SiC ball/ } \mathrm{Al}, \mathrm{Mg} \\
\text { or P-doped } \mathrm{SiC}\end{array}$ & $36 \mathrm{~mm} / \mathrm{s}$ & $1 \mathrm{~N}$ & $30 \%-60 \% \mathrm{RH}$ & $\begin{array}{l}\text { At higher humidity }(60 \% \mathrm{RH}) \text {, the friction } \\
\text { coefficient value }(0.25) \text { is almost indepen- } \\
\text { dent of doping elements. } \\
\text { At lower humidity }(30 \% \mathrm{RH}) \text {, the effect of } \\
\text { doping elements ( } \mathrm{Al}, \mathrm{Mg} \text { and } \mathrm{P}) \text { is more } \\
\text { pronounced. } \\
\text { As the humidity increases from } 30 \% \text { to } \\
60 \% \text {, the nature of damage changes from } \\
\text { mechanical to tribochemical. }\end{array}$ & 42) \\
\hline $\begin{array}{c}\mathrm{SiC}-\mathrm{MoSi}_{2} / \\
\text { Alumina cylinder }\end{array}$ & $\begin{array}{l}0.5,1.0 \text { and } \\
2.0 \mathrm{~m} / \mathrm{s}\end{array}$ & $\begin{array}{l}15,30 \text { and } \\
50 \mathrm{~N}\end{array}$ & $\begin{array}{c}20-25^{\circ} \mathrm{C} \\
\text { and } 35-55 \% \mathrm{RH}\end{array}$ & $\begin{array}{l}\text { Mild to severe wear transition with speed } \\
\text { (high wear at high speed of } 2 \mathrm{~m} / \mathrm{s} \text { ) }\end{array}$ & 90) \\
\hline $\begin{array}{l}\mathrm{SiC}_{\mathrm{f}} \mathrm{SiC} \\
\text { pin/hardened } \\
\text { steel disc }\end{array}$ & $\begin{array}{l}\sim 100 \text { to } \\
\sim 850 \mathrm{rpm}\end{array}$ & $11 \mathrm{~N}$ & Dry Atmosphere & $\begin{array}{l}\mathrm{SiC}_{\mathrm{f}} / \mathrm{SiC} \text { composite with carbon interface } \\
\text { shows high hardness and least wear rate. } \\
\mathrm{SiC}_{\mathrm{f}} \mathrm{SiC} \text { composite with } \mathrm{BN} \text { interface, } \\
\text { subjected to an intermediate heat treatment } \\
\text { showed lower hardness and higher wear } \\
\text { rate }\end{array}$ & 59) \\
\hline $\begin{array}{l}\mathrm{SiC} \text { or } \mathrm{Al}_{2} \mathrm{O}_{3} \\
\text { balls/ Pressure less } \\
\text { sintered } \mathrm{SiC} \text { disk }\end{array}$ & $\begin{array}{l}\text { Stroke } \\
100-1600 \mu \mathrm{m}, \\
\text { frequency } \\
2.5-20 \mathrm{~Hz}\end{array}$ & $1-10 \mathrm{~N}$ & 1 to $100 \% \mathrm{RH}$ & $\begin{array}{l}\text { Tribo-oxidation was determined as the main } \\
\text { wear mechanism. }\end{array}$ & 91) \\
\hline $\begin{array}{l}\mathrm{SiC} \text { cylinder/SiC } \\
\text { plate }\end{array}$ & $\begin{array}{l}\text { Stroke } 8 \mathrm{~mm}, \\
\text { frequency } 10 \mathrm{~Hz}\end{array}$ & $60 \mathrm{~N}$ & $\begin{array}{l}\text { Isooctane and } \\
\text { distilled water }\end{array}$ & $\begin{array}{l}\text { The self-mated ceramics showed greater } \\
\text { values of friction coefficient in isooctane } \\
\text { than in distilled water }\end{array}$ & $60)$ \\
\hline
\end{tabular}

a prolonged sliding. Important findings from sliding wear studies of $\mathrm{SiC}$ based ceramics are listed in Table 2 .

\subsection{Mechanisms of material removal in sliding wear}

In this section, studies relating to material removal mechanisms during sliding wear are discussed in terms of material characteristics. Different results for frictional behavior between varieties of pairs of $\mathrm{SiC}$ ceramics during wear indicate complexity in frictional mechanism. Kato ${ }^{92)}$ divided wear mechanisms of $\mathrm{SiC}$ ceramics in sliding wear conditions into two modes: (a) mechanical wear, where various types of cracks like lateral, median and radial cracks are generated by friction around the Hertzian contact zone (see Fig.6), and (b) tribo-chemical wear, where silicon oxide was found on the surface in unlubricated sliding wear..$^{93,94)}$

Wang et al $^{43)}$ found that tribological contact stresses predominantly affect mechanisms of material removal. They found that $\mathrm{SiC}$ ceramics removed via plastic deformation induced microfracture for less stress on contact surface. As the contact stress increased to a critical level, varieties of cracks like partial cone cracks, lateral/shallow cracks, and radial cracks etc. are generated. Further increase in contact stress propagates cracks to intersect each other and detach 


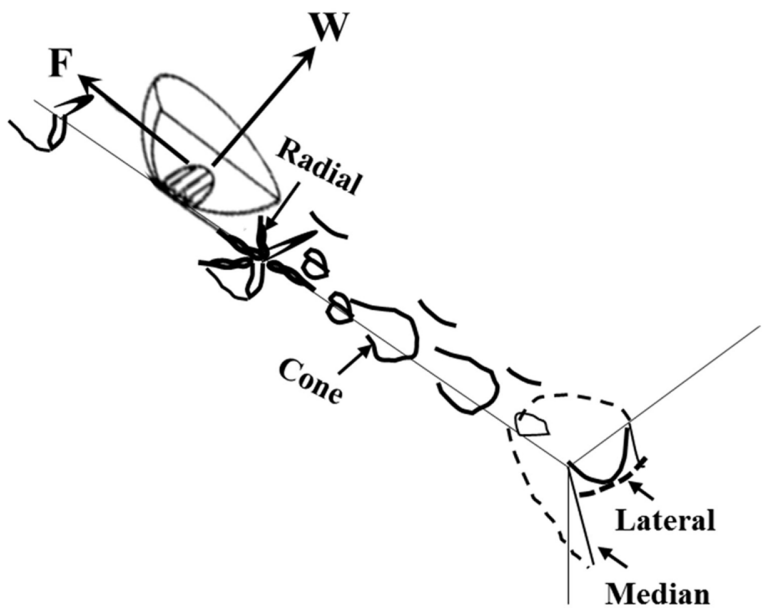

Fig. 6. Various types of cracks induced by friction in unlubricated sliding wear conditions. ${ }^{93)}$ (where $\mathrm{W}$ is load and $\mathrm{F}$ is frictional force).

chunks of material. The detached material crushed into fine particles by further tribological contact and evolved as wear debris. The dominant damage patterns with contact stress severity for indentation, scratch, and wear tests are synchronized in Table 3.

Lopez et al. ${ }^{51)}$ reported that for equiaxed-grained $\mathrm{SiC}$ ceramics, sliding wear initiated with plastic dislocation as mild wear and led to sever wear, with fracture and pull-out of material. ${ }^{37,69,85,95-96)}$ For coarser microstructures, transition in wear mechanism occurred sooner and exhibited poor wear resistance. $^{43,47,50,69-70,96-99)}$ However, these mechanisms were not observed for highly heterogeneous ceramics such as elongated-grain LPS-SiC. ${ }^{51)}$ For elongated grain LPS SiC ceramics, despite the grain-boundary fracture, interlocking network was responsible for the surface integrity of worn surface which delayed transition in wear mechanism.

Kovalcikova et $a l^{86)}$ studied wear mechanisms for $\mathrm{SiC}$ ceramics slid against different counterparts $\mathrm{Si}_{3} \mathrm{~N}_{4}, \mathrm{Al}_{2} \mathrm{O}_{3}$, WC-Co and $\mathrm{ZrO}_{2}$ materials. They found microfracture and removal of oxides against any counterpart. But the extent of material removal was different. The steady state coefficient of friction and specific wear rate were affected with different tribological partners. The $\mathrm{SiC} / \mathrm{Si}_{3} \mathrm{~N}_{4}$ couple exhibited the highest friction probably due to chemical similarity of counterparts.

Andersson et al. ${ }^{45)}$ reported two types of oxidation in sliding at elevated contact temperatures: passive oxidation and active oxidation. At elevated temperature (usually above $575^{\circ} \mathrm{C}$ ), $\mathrm{SiC}$ oxidizes to $\mathrm{SiO}_{2}$ according to the following reactions: ${ }^{100-101)}$

$$
\begin{aligned}
& 2 \mathrm{SiC}+3 \mathrm{O}_{2} \rightarrow 2 \mathrm{SiO}_{2}+2 \mathrm{CO} \text { (passive oxidation) } \\
& \mathrm{SiC}+2 \mathrm{O}_{2} \rightarrow \mathrm{SiO}_{2}+\mathrm{CO}_{2} \text { (passive oxidation) }
\end{aligned}
$$

Above reactions occur at an appropriate pressure in oxygen environment. If temperature is above $1000{ }^{\circ} \mathrm{C}$, with low partial pressures of oxygen, the following reactions might occur on $\mathrm{SiC}$ ceramic surface. ${ }^{101)}$

$$
\begin{aligned}
& \mathrm{SiC}+2 \mathrm{SiO}_{2} \rightarrow 3 \mathrm{SiO}+\mathrm{CO} \text { (active oxidation) } \\
& \mathrm{SiC}+\mathrm{O}_{2} \rightarrow \mathrm{SiO}+\mathrm{CO} \text { (active oxidation) }
\end{aligned}
$$

The $\mathrm{SiO}$ powder formed was brownish to yellowish in color and often formed with $\beta$-SiC powders in an argon thermal plasma jet. ${ }^{102)}$

Under passive oxidation layer, loose wear debris consisting of $\mathrm{SiO}_{2}$ formed a protective and less shear strength tribofilms which further favored to reduced wear rates. Against passive oxidation layer, wear rates varied from $10^{-6}$ to $10^{-5} \mathrm{~mm}^{3} / \mathrm{N}$.m and the coefficients of friction was approximately 0.5. As $\mathrm{SiO}$ did not form tribofilms and favored to active oxidation to some extent, wear rates increased to $10^{-5}$ $-10^{-4} \mathrm{~mm}^{3} / \mathrm{N} . \mathrm{m}$ and the coefficients of friction to 0.8 . It was found that the additive composition had minimal effect on frictional behavior of SiC ceramics under dry sliding conditions when compared to sliding load. ${ }^{2)}$ Wear mechanisms changed from surface grooving and micro-cracking at lower load $(1 \mathrm{~N})$ to dominant tribochemical wear at higher (6 or 13 N) load for all the ceramics. In other study, ${ }^{84)}$ sliding wear behavior of $\mathrm{SiC}$ ceramics sintered with ( $0.2 \mathrm{wt} . \%$ or 3 wt.\%) $\mathrm{Y}_{2} \mathrm{O}_{3}$ additive, microcracks induced fracture and pull-out were found responsible for the material removal.

In self-mated sliding of $\mathrm{SiC}$ ceramics, Gahr et $a l^{41)}$ reported that running-in period was much longer in vacuum than in humid air and would favor tribochemical smoothening of surface roughness. At a tribocontact of relatively

Table 3. Contact Stress Severity Against Damage Patterns for SiC Ceramics ${ }^{43}$

\begin{tabular}{cccc}
\hline \multirow{2}{*}{ Contact Stress } & \multicolumn{2}{c}{ Dominant damage patterns in sliding of SiC ceramics } \\
\cline { 2 - 4 } Small & Indentation & Scratch & Wear \\
\hline $\begin{array}{c}\text { Molerate } \\
\text { (below the plastic limit) } \\
\text { Large }\end{array}$ & $\begin{array}{c}\text { No damage } \\
\text { (Elastic Deformation) }\end{array}$ & $\begin{array}{c}\text { No damage } \\
\text { (Elastic Deformation) }\end{array}$ & $\begin{array}{c}\text { No damage } \\
\text { (Elastic Deformation) } \\
\text { Plastic deformation } \\
\text { controlled wear }\end{array}$ \\
$\begin{array}{c}\text { Plastic deformation } \\
\text { (near the critical failure stress) } \\
\text { Very large }\end{array}$ & Cone/Ring cracks & Plastic deformation & $\begin{array}{c}\text { Microcrack controlled wear } \\
\text { or grain pull-out }\end{array}$ \\
(exceeds the critical stress) & Radial crack & $\begin{array}{c}\text { Microfracture caused by the } \\
\text { intersection of radial, lateral and } \\
\text { partial cone cracks }\end{array}$ & $\begin{array}{c}\text { Microfractured-controlled } \\
\text { wear }\end{array}$ \\
\hline
\end{tabular}


smooth surface, formation of thin water film led to increased friction owing to menisci formed at asperities. On the other hand, thick water films separated the mated bodies and resulted for reduced friction due to low viscosity of $\mathrm{H}_{2} \mathrm{O}$ and assumed a proper wettability of tribosurfaces with water film, i.e. hydrophilic surfaces.

Available data on the effect of humidity on coefficient of friction and wear rate of self-mated $\mathrm{SiC}$ ceramics is compiled and presented as Fig. $7 .^{72,85,91,93)}$ Murthy et $a l .{ }^{72)}$ found that at lower humidity, major wear mechanism was fracture of tribosurface followed by attrition, while tribochemical reaction (oxidation or hydrolysis) was a leading wear mechanism at higher humidity. Owing to the availability of more water molecules, oxidation $\left(\mathrm{SiC}+2 \mathrm{H}_{2} \mathrm{O} \rightarrow \mathrm{SiO}_{2}+\mathrm{CH}_{4}\right)$ and hydrolysis $\left(\mathrm{SiO}_{2}+\mathrm{H}_{2} \mathrm{O} \rightarrow \mathrm{Si}(\mathrm{OH})_{4}\right)$ reactions were accelerated at higher humidity. The faster kinetics of tribochemical reactions resulted in decreased wear with a narrow difference in friction.

Li et $a l .{ }^{85)}$ observed difference in wear mechanism during sliding in water lubrication conditions for $\mathrm{SiC}$ ceramics prepared through different processing routes. The wear occurred by pull-out of grains, which was mainly controlled by free $\mathrm{Si}$ along grain boundary for the reaction sintered SiC. Tribochemical oxidation in water and local grain fracture occurred due to its low toughness for the pressureless sintered SiC. Excellent tribological properties and low friction were attributed for the hydrodynamic lubrication for the toughened $\mathrm{SiC}$. It was believed that tribochemical oxidation took place and an ultraflat surface consisting of $\mathrm{SiO}_{2}$ and $\left(\mathrm{SiO}_{2} \cdot \mathrm{nH}_{2} \mathrm{O}\right)$ formed on the worn track.

Candelaria et al. ${ }^{88)}$ found less wear of $\mathrm{SiC}$ with graphite nanodispersoids compared to $\mathrm{SiC}$ ceramics, due to the combination of (i) higher toughness, which hinders the crack propagation and coalescence responsible for the grain pullout, (ii) lower hardness of the wear debris due to its lower $\mathrm{SiC}$ concentration, and (iii) external lubrication imposed by pull-out of graphite nanoparticles, which reduced abrasion by third bodies. Zhu et al. ${ }^{103)}$ studied polishing of $\mathrm{SiC}$ ceram-

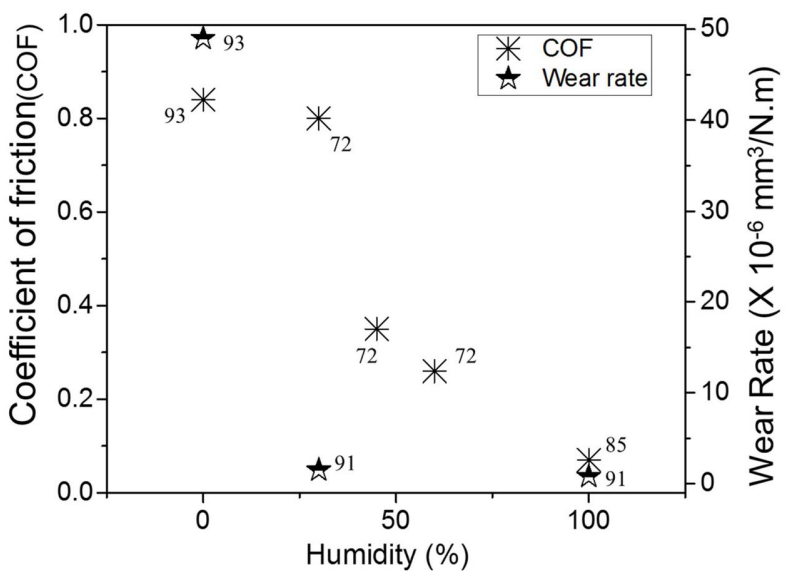

Fig. 7. Average steady state coefficient of friction and wear rate of $\mathrm{SiC}$ ceramic with respect to humidity against $\mathrm{SiC}$ counterbody. ${ }^{72,85,91 \text { and } 93 \text { ) }}$ ics in oxidant solution of $3 \mathrm{wt} \% \mathrm{CrO}_{3}$. The removal of material by a chemical dissolution, stimulated by friction was referred as tribochemical.

Ciudad et $a l .{ }^{74)}$ studied wear mechanisms in diesel for pressureless LPS-SiC. They found a two-step wear process, initially controlled by plastic deformation (corresponding to mild wear regime) followed by fracture of materials (corresponding to severe wear regime). Major characteristics of surfaces in mild wear and severe wear regimes are schematically illustrated in Fig. 8. Erickson et al. ${ }^{104)}$ observed chemical wear on mated surface as major deterioration mechanism in oil/water lubricated sliding conditions along with several mechanisms like plastic deformation, subsurface microcrack formation, microfracture and microabrasion of the surface of worn SiC. The absence of tribofilm on the contact surface indicates that wear debris transported out of the system or directly dissolved by the oil/water lubricant as water is able to dissolve $\mathrm{SiO}_{2}$ easily. ${ }^{105-107)}$

Zhou et $a l .{ }^{75)}$ reported that the tribochemical reaction led to material removal for monolithic $\mathrm{SiC}$ and $\mathrm{SiC}-\mathrm{C}$ (graphite) composite. For SiC, they found rough worn surfaces resulted in fracture and three body abrasion, whereas graphite particles exerted a lubricating effect and resulted lower coefficients of friction for the $\mathrm{SiC}-\mathrm{C}$ composites. Micele et $a l .{ }^{90)}$ studied the tribological characteristics of $\mathrm{SiC}-\mathrm{MoSi}_{2}$ composites against alumina in dry sliding. The material loss was caused by ploughing effects, while no significant effect of brittle fracture observed on the worn surface of the ceramic composite.

Recently, sliding wear mechanisms were studied for monolithic SiC and SiC-WC composites against SiC counterbody. ${ }^{76)}$ For monolithic $\mathrm{SiC}$ ceramics, blunt indenterinduced mechanical fracture with micro-cracking was found as dominant material removal mechanism, while WC addition reduced grain pull-out for SiC-WC composites leading to reduced wear rates. Analysis of debris collected from worn surfaces indicated increase in compaction or oxidation with WC addition. Wasche and Klaffke ${ }^{108)}$ studied the wear mechanism for $\mathrm{SiC}-\mathrm{TiC}-\mathrm{TiB}_{2}$ in water when slid against $\mathrm{SiC}$ or $\mathrm{Al}_{2} \mathrm{O}_{3}$. In case of $\mathrm{SiC} / \mathrm{SiC}$ and $\mathrm{Al}_{2} \mathrm{O}_{3} / \mathrm{SiC}$, no films were formed. An oxide film was formed during wear of $\mathrm{SiC}-\mathrm{TiC}$ and $\mathrm{SiC}-\mathrm{TiC}-\mathrm{TiB}_{2}$ materials. Reduction in wear of materials was affected by formation of titanium oxide at the tribocontact. In case of $\mathrm{Al}_{2} \mathrm{O}_{3}$ ball and composite disk system, the tribooxidatively formed layer was partly adhered on to the ball. The wear of $\mathrm{SiC}-\mathrm{TiC}$ or $\mathrm{SiC}-\mathrm{TiC}-\mathrm{TiB}_{2}$ disk against
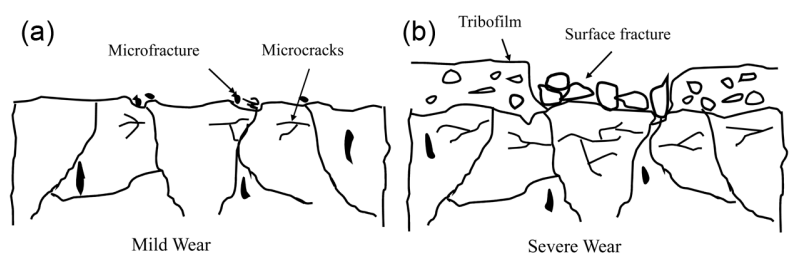

Fig. 8. Schematic illustrations of worn surface characteristics of SiC ceramics after sliding in diesel in (a) mild wear and (b) severe wear regimes. ${ }^{71}$ 
$\mathrm{SiC}$ or $\mathrm{Al}_{2} \mathrm{O}_{3}$ ball was reduced by a factor of 10 compared to monolithic $\mathrm{SiC}$ disk system.

\section{Erosion Wear of SiC Ceramics}

Erosion can be defined as removal of material from a surface due to interaction between the surface and a fluid, or impinging liquid or solid particles. ${ }^{65,109-110)}$ Considerable research has been carried out in understanding solid particle erosion wear behavior of $\mathrm{SiC}$ ceramics and their composites. ${ }^{62,65,67,109-117)}$

\subsection{Effect of microstructure and mechanical properties}

Solid particle erosion of $\mathrm{SiC}$ ceramics and their composites is reported to occur generally by brittle fracture as a result of lateral and radial cracking. ${ }^{62,67,110-113)}$ Bell and Rogers ${ }^{118)}$ noted fracture toughness as predominant factor in estimating erosion wear characteristics of brittle materials at normal impact of erodent, ${ }^{65,119)}$ whereas hardness was found important at low impingement angles. Shetty et al. ${ }^{120)}$ also reported hardness as predominant property of reactionbonded $\mathrm{SiC}$ ceramics to estimate erosion behavior of ceramics. Routbort and Matzke ${ }^{114}$ ) studied the erosion for $\mathrm{SiC}$ ceramics prepared through hot-pressing and reactionbonded sintering techniques. The Vickers hardness $(\mathrm{H})$ and fracture toughness $\left(\mathrm{K}_{\mathrm{IC}}\right)$ of these ceramics were used to estimate the erosion rate $(\Delta \mathrm{W})$ of ceramics using following equation:

$$
\Delta \mathrm{W}=\mathrm{C} \mathrm{H}^{\mathrm{a}} \mathrm{K}_{1 \mathrm{c}}^{\mathrm{b}}
$$

where, $\mathrm{C}$ is proportionality constant and the exponents a and $b$ valued according to details of the used erosion mod$\mathrm{el}^{114)}$ (see Table 4). However, the wear rates estimated using existing wear models were not in agreement with the experimentally measured wear rates. This can be primarily attributed to the fact that these models neglected important contributions from microstructure of the target material in estimating erosion loss. ${ }^{65-67,112-114)}$

Wang et al. ${ }^{65)}$ studied the effect of microstructure on erosive wear of $\mathrm{SiC}$ ceramics, prepared by pressureless sintering, hot pressing and hot isostatic pressing techniques. Microcracking with some extent of plastic deformation was observed as main material removal mechanism at higher impact angles. ${ }^{121-122)}$ Grain refinement and reduction in the amount and size of pores of hot isostatically pressed $\mathrm{SiC}$ resulted in superior wear resistance.

$\mathrm{SiC}$ ceramics sintered with 10, 30 or $50 \mathrm{wt} \%$ WC particles via hot press technique were subjected to erosion against $\mathrm{SiC}$ and alumina erodent. ${ }^{61)}$ Compared to erosion rates against alumina erodent, erosion rates against $\mathrm{SiC}$ erodent increased by two orders (from 10 to $10^{3} \mathrm{~mm}^{3} / \mathrm{kg}$ ) for normal impingement (see Table 5). SiC ceramics achieved steady state erosion after 5 min of erosion against $\mathrm{SiC}$ erodent which delayed to $20 \mathrm{~min}$ against alumina. Maximum erosion resistance was obtained for $\mathrm{SiC}$ ceramics sintered with $30 \mathrm{wt} \%$ WC which possessed maximum hardness. SiC ceramics sintered with $50 \mathrm{wt} \% \mathrm{WC}$ ceramics having highest fracture toughness showed lower wear resistance than $\mathrm{SiC}$ ceramics sintered with 30 wt\% WC (see Fig. 9). This implies that hardness played important role in erosion of SiC-WC composites. $^{61)}$

Table 4. Values of $\left(\mathrm{H}^{\mathrm{a}} \mathrm{K}_{\mathrm{Ic}}{ }^{\mathrm{b}}\right)$ Calculated for the Various Steadystate Erosion Models and Experimentally Measured Erosion Rates for SiC Ceramics. ${ }^{114)} \mathrm{HP}-\mathrm{SiC}$ and RB$\mathrm{SiC}$ rEspectively Indicate Hot Pressed $\mathrm{SiC}$ And Reaction bonded $\mathrm{SiC}$, while $\mathrm{H}$ and $\mathrm{K}_{\mathrm{Ic}}$ Indicate Hardness and Fracture Toughness, Respectively

\begin{tabular}{ccccc}
\hline Materials & $\mathrm{H}^{0.11} \mathrm{~K}_{\mathrm{Ic}}^{-1.3} \mathrm{H}^{-0.25} \mathrm{~K}_{\mathrm{Ic}}^{-1.3} \mathrm{H}^{0.48} \mathrm{~K}_{\mathrm{Ic}}^{-1.9}$ & $\begin{array}{c}\text { Measured } \\
\text { Erosion Rate } \\
\left(\times 10^{-3} \mathrm{~g} / \mathrm{g}\right)\end{array}$ \\
\hline $\mathrm{HP}-\mathrm{SiC}$ & 0.54 & 0.01 & 11.10 & 2.00 \\
$\mathrm{RB}-\mathrm{SiC}$ & 1.34 & 0.03 & 40.00 & 12.00 \\
$\mathrm{RB}-\mathrm{SiC}+$ & 0.73 & 0.02 & 16.20 & 10.00 \\
$\begin{array}{c}0.2 \mathrm{vol} \% \mathrm{Si} \\
\mathrm{RB}-\mathrm{SiC}+\end{array}$ & 0.80 & 0.02 & 18.00 & 4.50 \\
$0.13 \mathrm{vol} \% \mathrm{Si}$ & & & & \\
\hline
\end{tabular}

Table 5. Average Erosion Rates of SiC-WC Composites at Normal Impact of Alumina and Silicon Carbide Erodents $^{61}$

\begin{tabular}{ccc}
\hline \multirow{2}{*}{ Material } & \multicolumn{2}{c}{ Average erosion rate $\left(\mathrm{mm}^{3} / \mathrm{kg}\right)$} \\
\cline { 2 - 3 } & Alumina erodent & Silicon carbide erodent \\
\hline SiC ceramics & 18.31 & 1044.63 \\
SiC- 30 wt\% WC & 6.57 & 850.73 \\
SiC- 50 wt\% WC & 20.49 & 1223.24 \\
\hline
\end{tabular}
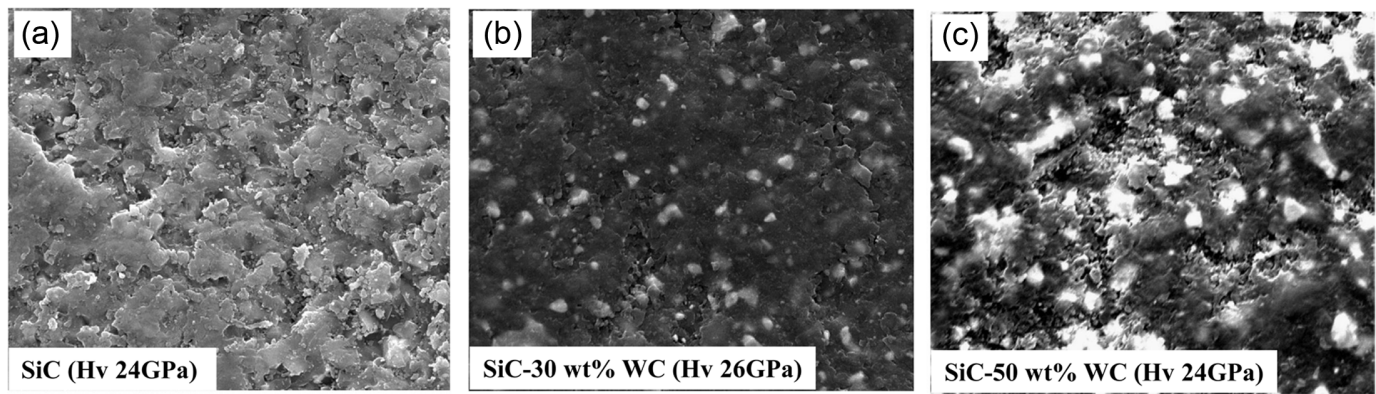

Fig. 9. Eroded surfaces of (a) $\mathrm{SiC}$ (b) SiC-30 wt \% WC and (c) SiC-50 wt \% WC composites at normal impact of SiC erodent. ${ }^{61)}$ Hardness data for the respective ceramics is also shown. 
Wang and Levy ${ }^{121)}$ studied the erosion behavior of $\mathrm{SiC}$ fiber reinforced $\mathrm{SiC}$ composite at $25^{\circ} \mathrm{C}$ and $850^{\circ} \mathrm{C}$ and found an inverse relation of density and hardness to the erosion rate of the composite. The erosion rate reduced by one order of magnitude at $850^{\circ} \mathrm{C}(0.10 \mathrm{mg} / \mathrm{g})$ compared to that at $25^{\circ} \mathrm{C}$ $(2.20 \mathrm{mg} / \mathrm{g})$. At $850^{\circ} \mathrm{C}$, the difference between erosion rates at $90^{\circ}$ and $30^{\circ}(0.02 \mathrm{mg} / \mathrm{g})$ was much less than that found at $25^{\circ} \mathrm{C}(1 \mathrm{mg} / \mathrm{g})$, which attributed to increased ductility of composite at $850^{\circ} \mathrm{C}$. Similarly in a recent study, ${ }^{63)}$ solid particle erosion rate of $\mathrm{SiC}-\mathrm{Si}_{3} \mathrm{~N}_{4}$ composite at elevated temperature increased firstly up to $800^{\circ} \mathrm{C}$, and then decreased with increase in temperature to $1400^{\circ} \mathrm{C}$. At lower temperature (up to $800^{\circ} \mathrm{C}$ ), wear occurred by brittle fracture where stripping of aggregates of composite resulted in loss of protection from the matrix. On the other hand, plastic deformation and oxidation protection dominated at higher temperature (beyond $800^{\circ} \mathrm{C}$ ). The highest erosion rate at $800^{\circ} \mathrm{C}$ for $\mathrm{SiC}_{-} \mathrm{Si}_{3} \mathrm{~N}_{4}$ is contradictory to the lowest erosion at $850^{\circ} \mathrm{C}$ for $\mathrm{SiC}$ ceramics. ${ }^{64)}$

Amirthan et $a l^{124)}$ found cleavage like brittle fracture on biomorphic $\mathrm{Si} / \mathrm{SiC}$ composite surface exposed to erosion. Fine teak wood particle based $\mathrm{Si} / \mathrm{SiC}$ composite showed least erosion compared to other $\mathrm{Si} / \mathrm{SiC}$ composite. Further, coarse teak wood particle based $\mathrm{Si} / \mathrm{SiC}$ composite with large pores caused the highest erosion rate. Lopez et al. ${ }^{125)}$ studied the erosion behavior of biomorphic (eucalyptus and pine reinforced) $\mathrm{SiC}$, reaction-bonded $\mathrm{SiC}$, and hot-pressed $\mathrm{SiC}$ and found that erosion resistance was highest for biomorphic based SiC ceramics. Owing to the highest hardness, hot-pressed $\mathrm{SiC}$ exhibited least erosion rate.

\subsection{Mechanisms of material removal in erosion wear}

The dominant mechanisms of material removal in solid particle erosion wear conditions of brittle ceramics are elastic-plastic deformation based micro-fracture, and crack formation below the plastic zone of subsurface. ${ }^{62,67,110-112)}$ Major findings from studies on erosion wear mechanisms for $\mathrm{SiC}$ ceramics are listed in Table 6.

A detailed investigation of impact sites of worn surface in brittle materials exhibits an intense plastic deformation beneath the immediate area of the contact. ${ }^{126-129)}$ The elasticplastic zone at the impact site is the major driving force for the surface fracture that led to material loss on erosion. ${ }^{130-132)}$ The residual stresses generated under plastic zone on impact of erodent to the brittle materials originate small lateral cracks to grow beneath the impact sites. Initially

Table 6. Summary of Major Findings from Studies on Erosion Wear Mechanism for SiC Based Ceramics

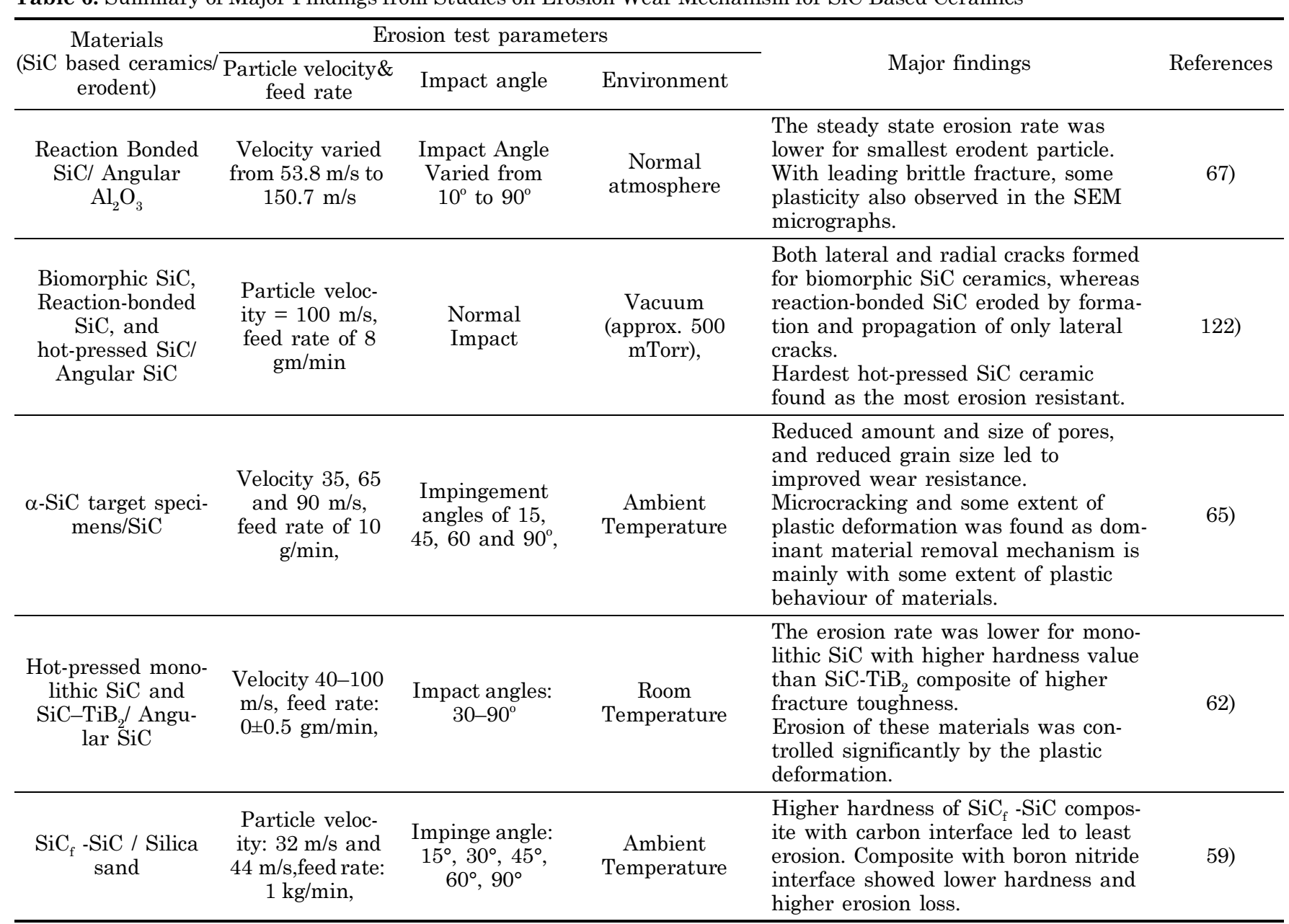




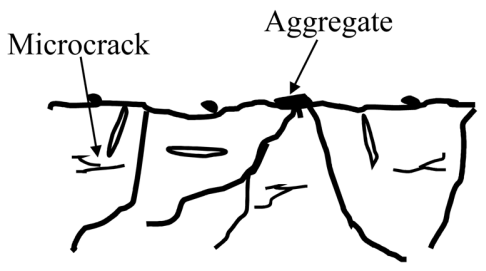

At $25^{\circ} \mathrm{C}$

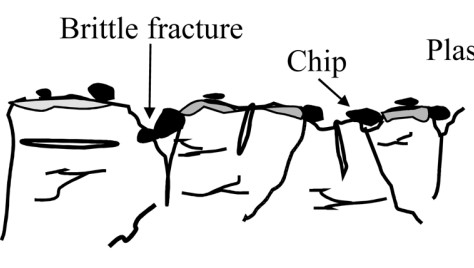

At $800^{\circ} \mathrm{C}$
Protective glassy film

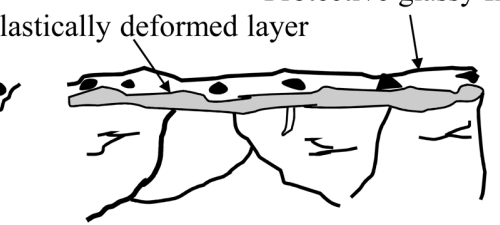

At $1400{ }^{\circ} \mathrm{C}$

Fig. 10. Schematic representation of erosion mechanisms for $\mathrm{SiC}_{-} \mathrm{Si}_{3} \mathrm{~N}_{4}$ composites at different temperatures. ${ }^{63)}$

these cracks propagate parallel to the impacted zone of target surface and further interact to the surface resulting in material loss. Wang and $\mathrm{Mao}^{133)}$ observed that size and type of cracks generated on the eroded surface are dependent on several factors like erodent shape and size, mass flow rate, velocity and angle of impingement of erodent, temperature and hardness, toughness and microstructure of target material. $^{61,65,113-114)}$

Two types of crack systems are generally found in erosion at low velocities; (a) cone cracks generated due to impact of blunt (rounded) erodent ${ }^{13,134-135)}$ and (b) lateral and median cracks generated due to impact of sharp (angular) erodent angular. $^{113,126,136-137)}$ In case of high velocities of erodent, material is removed by plowing, severe cracking and chipping. ${ }^{110,113,130,132,134)}$ In other study, ${ }^{67)}$ precise mechanisms for the erosion of reaction bonded-SiC were not clear, but reduced erosion wear rate of mixed phase $\mathrm{SiC}-\mathrm{Si}$ region was related to either by arresting of cracks around the small $\mathrm{SiC}$ grains or by increased apparent volume fraction of uncovered erosion resistant fine $\mathrm{SiC}$ grains of the two-phase region, generated beneath the impacted sites.

Suh et $a l .{ }^{137}$ studied the effect of $\mathrm{SiC}$ fiber reinforcement on erosion wear of $\mathrm{SiC}$ ceramics. During erosion of the composite, initially $\mathrm{SiC}$ fibers were detached from the interface and matrix of SiC subsequently eroded out. Pores presented in matrix with aperture around the fibers led to easy removal of material from the impact sites. The erosion wear was also attributed to issues regarding durability and reliability that depend on geometric discordance, irregular performance, and related energy dissipation.

Gochnour et al. ${ }^{138)}$ studied erosion behavior of $\mathrm{SiC}^{2} \mathrm{Al}_{2} \mathrm{OC}$ composites against alumina erodent. They found surface appeared smooth and polished, with grain pull-out regions in erosion of $\mathrm{SiC}-5 \mathrm{wt} \% \mathrm{~A}_{2} \mathrm{OC}$ composites. Softer $\mathrm{Al}_{2} \mathrm{OC}$ phases resulted in grain pull-out regions and smooth zones were corresponded to wear of harder SiC phase. However, severe grain pull-out occurred in erosion of SiC-50 wt \% $\mathrm{A}_{2} \mathrm{OC}$ composite and resulted in isolated smooth regions only. The steady-state erosion rate $(\Delta \mathrm{E})$ for brittle materials was proportional to erodent size and found to be related as

$$
\Delta \mathrm{E} \propto \mathrm{R}^{2 / 3}
$$

where $\mathrm{R}$ is the erodent radius. ${ }^{113,139)}$ This was predicted by both the dynamic ${ }^{113)}$ and the quasi-static ${ }^{139)}$ theories of erosion for brittle materials. However, Kim and Park ${ }^{140)}$ found that erosion rates of $\mathrm{SiC}$ and $\mathrm{SiC}-\mathrm{TiB}_{2}$ were not increased monotonically with the increased erodent size, in contrast to the prediction by theories. The eroded surface of $\mathrm{SiC}$ exhibited deformed lips and cracks, whereas intergranular fracture observed together with deformed lips for $\mathrm{SiC}^{-\mathrm{TiB}_{2}}$ composite.

Limited reports are available on erosion behavior of $\mathrm{SiC}$ ceramics and composites as function of temperature. Wang and Levy ${ }^{64)}$ reported that erosion for SiC fiber reinforced $\mathrm{SiC}$ composite at $25^{\circ} \mathrm{C}$ occurred by cracking and chipping of the matrix as well as the fibers, while erosion rates considerably decreased at $850{ }^{\circ} \mathrm{C}$ owing to the increased ductility. Li et $a l .{ }^{63)}$ studied the erosion mechanism for $\mathrm{SiC}_{-} \mathrm{Si}_{3} \mathrm{~N}_{4}$ composites at different temperatures $\left(25{ }^{\circ} \mathrm{C}-1400{ }^{\circ} \mathrm{C}\right)$. At low temperature, material removal occurred mainly by brittle fracture and stripping of aggregates as the protection from the matrix was lost. At higher temperature, erosion mechanisms were primarily ascribed to plastic deformation as well as oxidation protection. Oxidation of $\mathrm{Si}_{3} \mathrm{~N}_{4}$ and $\mathrm{SiC}$ on the material surface at $1400{ }^{\circ} \mathrm{C}$ generated a thin dense layer of $\mathrm{SiO}_{2}$ glassy film, which further reduced direct contact of erodent with the material surface at a certain extent and resulted in less loss of the material (illustrated schematically as Fig. 10). ${ }^{141)}$

\section{Summary and Future Scope}

Considering the wide range of tribological applications, wear behavior of $\mathrm{SiC}$ and its composites is extensively studied. In the present review, tribological characteristics of $\mathrm{SiC}$ ceramics and composites in sliding and solid particle erosion conditions are comprehensively discussed.

It is found during sliding that wear and friction characteristics of $\mathrm{SiC}$ ceramics vary with microstructural alteration. Hard interlocking network of elongated grains or high aspect ratio grains led to enhanced wear resistance. Second phases and intergranular phases also play a dominant role on wear and friction behavior. SiC ceramics with reduced weak second phase content and grain refinement exhibited improved wear resistance. Further, SiC ceramics with clear grain boundaries showed improved wear resistance compared to amorphous grain boundaries. The transition from mild to severe wear occurs for $\mathrm{SiC}$ ceramics with coarse grain structure than with fine grain structure. Doping elements affect kinetics of tribochemical reaction and lead to different characteristics of friction and wear. In understand- 
ing the influence of mechanical properties on wear of $\mathrm{SiC}$ ceramics, research is mainly debated on the dominant effect of fracture toughness and hardness. It is widely accepted that crack deflection or crack bridging by reinforced phase led to less extent of material removal during sliding wear of $\mathrm{SiC}$ composites. Furthermore, the ratio of hardness and fracture toughness $\left(\mathrm{H} / \mathrm{K}_{1 \mathrm{c}}\right)$, known as brittleness index is found to give qualitative estimation of wear for $\mathrm{SiC}$ ceramics. Superior resistance to wear was found for ceramics with high brittleness index. Reinforced phases like graphene nanodispersoids led to an increase in fracture toughness and reduced hardness, the combination of which reduced the mild to severe wear transition.

Sliding wear mechanisms of $\mathrm{SiC}$ ceramics and composites can be categorized into two groups: mechanical and tribochemical. In mechanical wear, cracks and abrasion dominate the worn surfaces of $\mathrm{SiC}$ ceramics, whereas oxides were found on the tribosurface in tribochemical wear. With regards to contact stress conditions, wear occurred trough plastic deformation induced microfracture in low contact stress, whereas cracks induced fracture led to material removal in high contact stress. High friction is found against the counterbody having chemical similarity with $\mathrm{SiC}$ ceramics, whereas composition of sintering additives had minimal effect on frictional behavior of $\mathrm{SiC}$ ceramics. At elevated sliding temperature, two types of oxidation: passive oxidation with reduced wear and active oxidation with increased wear are reported for $\mathrm{SiC}$ ceramics. Running-in period is reported to be higher in vacuum than in humid air for SiC ceramics. Tribochemical smooth layer formed in humid air led to less friction. During oil/diesel fuel lubrication, wear occurred in two steps: initially controlled by plastic deformation and then followed by subsurface microcrack formation, microfracture and micro-abrasion.

Solid particle erosion rate is found to be higher whereas steady states attained earlier against harder erodent particles. Erosion resistance is improved for harder SiC ceramics. Grain refinement and reduced amount and size of pores resulted for superior resistance against erosion. Erosion rates of $\mathrm{SiC}$ ceramics were estimated by semi-empirical models with mechanical properties like hardness, fracture toughness and elastic modulus. Since none of the proposed models for erosion prediction/estimation was completely satisfactory, it advocated necessary incorporation of microstructural aspects into erosion theories. Incorporation of $\mathrm{SiC}$ fibers in $\mathrm{SiC}$ matrix resulted in improved erosion resistance at elevated temperature. The difference in erosion rate with change in impingement angle of erodent also found to be less at high temperature. In general, erosion rate of $\mathrm{SiC}$ composites increased with increase in temperature up to $800^{\circ} \mathrm{C}$ and attributed to brittle fracture and stripping of aggregates. Further increase in temperature up to $1400^{\circ} \mathrm{C}$ resulted in the formation of silica based glassy film and decreased erosion.

Solid particle erosion for $\mathrm{SiC}$ ceramics is reported to occur by elastic-plastic deformation based microfracture followed by subsurface crack formation beneath the plastic zone. Size and type of cracks are found to dependent on erodent shape and size, mass flow rate, velocity and angle of impingement of erodent, temperature, hardness toughness and microstructure of target materials. In case of low velocities of erodent, dependent on shape of the erodent, two types of cracks were generally reported. On impact of blunt erodent, generation of cone cracks are observed whereas lateral and/or median cracks are generated beneath the plastically deformed surface against sharp erodent. For high velocities impact of erodent, material removal from target surface is removed by plowing, severe cracking and chipping. Erosion wear of $\mathrm{SiC}$ ceramics was dependent on the characteristics of second phase such as geometry, durability, energy dissipation etc. During erosion, $\mathrm{SiC}$ fiber reinforced $\mathrm{SiC}$ composites initially detached out of matrix which further left pores and then resulted in easy removal of SiC ceramics. Shape, size and size distribution of erodent particles influence erosion of $\mathrm{SiC}$ ceramic composites.

The future scope of tribological characteristics of $\mathrm{SiC}$ ceramics and composites can be realized. The incorporation of microstructural parameters in contemporary wear model/ theories is essential to estimate material removal in sliding or erosion conditions. Most of the studies reported high temperature wear behavior using mechanical and microstructural characteristics of $\mathrm{SiC}$ ceramics estimated at ambient temperatures, whereas the effect of mechanical and microstructural features at elected temperatures is to be considered for estimating true potential. Furthermore, SiC ceramics and composites have not been considerably studied for understanding their behavior in low temperature wear applications. A future study on the effect of mechanical or microstructural characteristics at low temperature would explore the potential of $\mathrm{SiC}$ ceramics and composites for their use in space or marine applications. Also, the physics of degradation in different wear conditions has to be thoroughly understood. Considering expected improvement of properties in nano composites, the wear behavior of $\mathrm{SiC}$ nano ceramics or nano composites is also to be investigated. Studies can also be extended to understand the performance $\mathrm{SiC}$ based cermets for their attractive combination of hardness and fracture toughness. Material removal mechanisms of $\mathrm{SiC}$ ceramics in other types of wear like cavitation wear, fretting wear, slurry erosion, corrosion wear etc. are to be thoroughly understood. While most of the reported studies are focused on understanding the behavior in aerospace, automotive, chemical, manufacturing, defense applications, exploring tribological potential of $\mathrm{SiC}$ composites for their use in other important fields like nuclear, biomedical, electronics etc. is also a prospective future direction.

\section{Acknowledgements}

B.V. Manoj Kumar acknowledges partial support from Council of Scientific and Industrial Research (CSIR), New Delhi, India through project No.22 (0654)/14/EMR-II. Valu- 
able suggestions from Professor Bikramjit Basu of Indian Institute of Science, Bangalore, India are appreciated.

\section{REFERENCES}

1. G. Roewer, U. Herzog, K. Trommer, E. Muller, and S. Fruhauf, "Silicon Carbide-A Survey of Synthetic Approaches, Properties and Applications," Struct. Bond., 101 59-135 (2002).

2. B. V. M. Kumar, Y.-W. Kim, D. S. Lim, and W. S. Seo, "Influence of Small Amount of Sintering Additives on Unlubricated Sliding Wear Properties of SiC Ceramics," Ceram. Int., 37 [8] 3599-608 (2011).

3. N. P. Padture, "In Situ-Toughened Silicon Carbide," J. Am. Ceram. Soc., 77 519-23 (1994).

4. P. T. B. Shaffer, "A Review of the Structure of Silicon Carbide," Acta Cryst., B, 25 477-88 (1969).

5. H. P. Iwata, U. Lindefelt, S. Oberg, and P.R. Briddon, "Stacking Faults in Silicon Crabides," Phys. B, 340-342 165-70 (2003).

6. Y. M. Tairov and V. F. Tsvetkov, "Investigation of Growth Processes of Ingots of Silicon Carbide Single Crystals," J. Crys. Growth, 43 [2] 209-12 (1978).

7. A. J. Van Bommel, J. E. Crombeen, and A. V. Tooren, "Leed and Auger Electron Observations of the SiC (0001) Surface," Surf. Sci., 48 463-72 (1975).

8. A. Taylor and D. S. Laidler, "The Formation and Crystal Structure of Silicon Carbide," Br. J. Appl. Phys., 1 [7] 174-81 (1950).

9. W. Wesch, "Silicon Carbide: Synthesis and Processing," Nucl. Instrum. Meth. B, 116 305-21 (1996).

10. V. A. Izhevskyi, L. A. Genova, J. C. Bressiani, and A. H. A. Bressiani, "Silicon Carbide. Structure, Properties and Processing," Ceramica, 46 4-13 (2000).

11. T. Hase, "Boron Transport and Change of Lattice Parameter during Sintering of $\beta$-SiC," J. Am. Ceram. Soc., 63 [56] 349-50 (1980).

12. K. Negita, "Effective Sintering Aids for Silicon Carbide Ceramics: Reactivities of Silicon Carbide with Various Additives," J. Am. Ceram. Soc., 69 [12] C308-10 (1986).

13. D. Sciti, S. Guicciardi, and A. Bellosi, "Effect of Annealing Treatment on Microstructure and Mechanical Properties of Liquid-Phase Sintered Silicon Carbide," J. Eur. Ceram. Soc., 21 621-32 (2001).

14. D. I. Cheong, J. Kim, and S. J. Kang, "Effect of Isothermal Annealing on the Microstructure and Mechanical Properties of $\mathrm{SiC}$ Ceramics Hot-Pressed with $\mathrm{Y}_{2} \mathrm{O}_{3}$ and $\mathrm{Al}_{2} \mathrm{O}_{3}$ Additions," J. Eur. Ceram. Soc., 22 1321-27 (2002).

15. D. Sciti and A. Bellosi, "Effects of Additives on Densification, Microstructure and Properties of Liquid-Phase Sintered Silicon Carbide" J. Mater. Sci., 35 3849-55 (2000).

16. G. Rixecker, I. Wiedmann, A. Rosinus, and F. Aldinger, "High-Temperature Effect in the Fracture Mechanical Behaviour of Silicon Carbide Liquid-Phase Sintered with AlN-Y $\mathrm{O}_{3}$ Additives," J. Eur. Ceram. Soc., 21 1013-19 (2001).

17. R. R. Lee and W. C. Wei, "Fabrication, Microstructure, and Properties of SiC-AlN Ceramic Alloys," Ceram. Eng.
Sci. Proc., 11 [7-8] 1094-121 (1990).

18. S. G. Lee, Y.-W. Kim, and M. Mitomo, "Relationship between Microstructure and Fracture Toughness of Toughened Silicon Carbide Ceramics," J. Am. Ceram. Soc., 84 1347-53 (2001).

19. H. J. Choi, J. G. Lee, and Y.-W. Kim, "Oxidation Behavior of Liquid-Phase Sintered Silicon Carbide with Aluminum Nitride and Rare-Earth Oxides $\left(\operatorname{Re}_{2} \mathrm{O}_{3}\right.$, where $\mathrm{Re}=\mathrm{Y}$, Er, Yb)," J. Am. Ceram. Soc., 85 [9] 2281-86 (2002).

20. Y. Zhou, K. Hirao, Y. Yamauchi, and S. Kanzaki, "Tailoring the Mechanical Properties of Silicon Carbide Ceramics by Modification of the Intergranular Phase Chemistry and Microstructure," J. Eur. Ceram. Soc., 22 2689-96 (2002).

21. D. Chen, X. F. Zhang, and R. O. Ritchie, "Effects of GrainBoundary Structure on the Strength, Toughness, and Cyclic-Fatigue Properties of a Monolithic Silicon Carbide," J. Am. Ceram. Soc., 83 2079-81 (2000).

22. R. Yuan, J. J. Kruzic, X. F. Zhang, L. C. De Jonghe, and R. O. Ritchie, "Ambient to High Temperature Fracture Toughness and Cyclic Fatigue Behavior in Al Containing Silicon Carbide Ceramics," Acta Mater., 51 6477-91 (2003).

23. P. F. Becher, "Microstructural Design of Toughened Ceramics," J. Am. Ceram. Soc., 74 255-269 (1991).

24. H. J. Choi, Y. -W. Kim, M. Mitomo, T. Nishimura, J. H. Lee, and D. Y. Kim, "Intergranular Glassy Phase Free $\mathrm{SiC}$ Ceramics Retains Strength at $1500^{\circ} \mathrm{C}$," Scripta Mater., 50 1203-7 (2004).

25. Y. -W. Kim, S. H. Lee, T. Nishumura, and M. Mitomo, "Heat-Resistant Silicon Carbide with Aluminum Nitride and Scandium Oxide," Acta Mater., 53 4701-8 (2005).

26. Y.-W. Kim, J. H. Lee, and D. Y. Kim, "Effect of Sintering Additive Composition on Grain Boundary Structure in Liquid-Phase-Sintered Silicon Carbide," Mater. Sci. Forum, 558-559 897-902 (2007).

27. B. V. M. Kumar, M. H. Roh, Y.-W. Kim, W. Kim, S. W. Park, and W. S. Seo, "Effect of Additive Composition on Microstructure and Mechanical Properties of $\mathrm{SiC}$ Ceramics Sintered with Small Amount of $\mathrm{RE}_{2} \mathrm{O}_{3}$ (RE: Sc, Lu, Y) and AlN," J. Mater. Sci., 44 5939-5943 (2009).

28. Y.-W. Kim, Y. S. Chun, T. Nishumura, M. Mitomo, and Y. H. Lee, "High Temperature Strength of Silicon Carbide Ceramics Sintered with Rare-Earth Oxide and Aluminum Nitride," Acta Mater., 55 727-36 (2007).

29. N. P. Padture, "In Situ-Toughened Silicon Carbide," J. Am. Ceram. Soc., 77 519-23 (1994).

30. G. Rixecker, K. Biswas, A. Rosinus, S. Sharma, I. Wiedmann, and F. Aldinger, "Fracture Properties of $\mathrm{SiC}$ Ceramics with Oxynitride Additives," J. Eur. Ceram. Soc., 22 2669-75 (2002).

31. K. Strecker and M. J. Hoffmann, "Effect of AlN-Content on the Microstructure and Fracture Toughness of HotPressed a Heat-Treated LPS-SiC Ceramics," J. Eur. Ceram. Soc., 25 801-7 (2005).

32. M. Herrmann, G. Standke, S. Hohn, G. Himpel, and T. Gestrich, "High-Temperature Corrosion of Silicon Carbide Ceramics by Coal Ashes," Ceram. Int., 40 1471-79 (2014).

33. Y. -W. Kim, K. Y. Lim, and W. S. Seo, "Microstructure 
and Thermal Conductivity of Silicon Carbide with Yttria and Scandia," J. Am. Ceram. Soc., 97 923-28 (2014).

34. K. Y. Lim, Y.-W. Kim, and K. J. Kim, "Mechanical Properties of Electrically Conductive Silicon Carbide Ceramics," Ceram. Int., 40 10577-82 (2014).

35. S. Grasso, T. Saunders, H. Porwal, and M. Reece, "UltraHigh Temperature Spark Plasma Sintering of $\alpha$-SiC," Ceram. Int., 41 225-30 (2015).

36. S. Lafon-Placette, K. Delbe, J. Denape, and M. Ferrato, "Tribological Characterization of Silicon Carbide and Carbon Materials," J. Eur. Ceram. Soc., 35 1147-59 (2015).

37. S. M. Hsu and M. Sheng, "Wear Prediction of Ceramics," Wear, 256 867-78 (2004).

38. D. Chen, X. F. Zhang, and R. O. Ritchie, Effects of GrainBoundary Structure on the Strength, Toughness, and Cyclic-Fatigue Properties of a Monolithic Silicon Carbide," J. Am. Ceram. Soc., 83 2079-81 (2000).

39. X. Dong, S. Jahanmir, and L. K. Ives, "Wear Transition Diagram for Silicon Carbide," Tribo. Int., 28 559-72 (1995).

40. D. C. Cranmer, "Friction and Wear Properties of Monolithic Silicon-Based Ceramics," J. Mater. Sci., 20 2029-37 (1985).

41. K. H. Z. Gahr, R. Blattner, D. H. Hwang, and K. Pohlmann, "Micro- and Macro-Tribological Properties of SiC Ceramics in Sliding Contact," Wear, 250 299-310 (2001).

42. V. S. R. Murthy, H. Kobayashi, S. Tsurekawa, N. Tamari, T. Watanabe, and K. Kato, "Influence of Humidity and Hoping Elements on the Friction and Wear of $\mathrm{SiC}$ in Unlubricated Sliding," Tribo. Int., 37 353-64 (2004).

43. Y. Wang and S. M. Hsu, "Wear and Wear Transition Mechanisms of Ceramics," Wear 195 112-22 (1996).

44. X. F. Zhang, G. Y. Lee, D. Chen, R. O. Ritchie, and L. C. D. Jonghe, "Abrasive Wear Behavior of Heat-Treated ABC-Silicon Carbide," J. Am. Ceram. Soc., 86 1370-78 (2003).

45. P. Andersson and A. Blomberg, "Instability in the Tribochemical Wear of Silicon Carbide in Unlubricated Sliding Contacts," Wear, 174 1-7 (1994).

46. O. O. Adewoye and T. F. Page, "Frictional Deformation and Fracture in Polycrystalline $\mathrm{SiC}$ and $\mathrm{Si}_{3} \mathrm{~N}_{4}$, " Wear, 70 37-5 (1981).

47. S. J. Cho, C. D. Um, and S. S. Kim, "Wear and Wear Transition in Silicon Carbide Ceramics During Sliding," J. Am. Ceram. Soc., 79 1247-51 (1996).

48. O. B. Lopez, A. L. Ortiz, F. Guiberteau, and N. P. Padture, "Sliding-Wear-Resistant Liquid-Phase-Sintered SiC Processed Using $\alpha$-SiC Starting Powders," J. Am. Ceram. Soc., 90 [2] 541-45 (2007).

49. O. B. Lopez, A. L. Ortiz, F. Guiberteau, and N. P. Padture, "Microstructural Design of Sliding-Wear-Resistant Liquid-Phase-Sintered SiC: An Overview," J. Eur. Ceram. Soc., 27 3351-57 (2007).

50. O. B. Lopez, A. L. Ortiz, F. Guiberteau, and N. P. Padture, "Effect of Microstructure on Sliding-Wear Properties of Liquid-Phase-Sintered $\alpha$-SiC," J. Am. Ceram. Soc., 88 [8] 2159-2163 (2005).

51. O. B. Lopez, A. L. Ortiz, F. Guiberteau, and N. P. Pad- ture, "Improved Sliding-Wear Resistance in In-situ Toughened Silicon Carbide,” J. Am. Ceram. Soc., 88 [12] 3531-34 (2005).

52. O. B. Lopez, A. L. Ortiz, F. Guiberteau, and N. P. Padture, "Effect of the Nature of the Intergranular Phase on Sliding-Wear Resistance of Liquid-Phase-Sintered $\alpha$ SiC," Scripta Mater., 57 [6] 505-8 (2007).

53. E. Ciudad, O. B. Lopez, F. Rodriguez-Rojas, A. L. Ortiz, and F. Guiberteau, "Effect of Intergranular Phase Chemistry on the Sliding-Wear Resistance of Pressureless Liquid-Phase-Sintered $\alpha$-SiC,” J. Eur. Ceram. Soc., 32 [2] 511-16 (2012).

54. A. L. Ortiz, O. B. Lopez, M. Z. Quadir, and F. Guiberteau, "A Route for the Pressureless Liquid-Phase Sintering of $\mathrm{SiC}$ with Low Additive Content for Improved SlidingWear Resistance," J. Eur. Ceram. Soc., 32 [4] 965-73 (2012).

55. R. S. Gates and S. M. Hsu, "Tribochemistry between Water and $\mathrm{Si}_{3} \mathrm{~N}_{4}$ and SiC: Induction Time Analysis," Tribol. Lett., 17 [3] 399-407 (2004).

56. S. M. Hsu and M. C. Shen, "Ceramic Wear Maps," Wear, 200 [1-2] 154-75 (1996).

57. K. Kato and K. Adachi, "Wear of Advanced Ceramics," Wear, 253 [11-12] 1097-104 (2002).

58. L. Jordi, C. Iliev, and T. E. Fischer, "Lubrication of Silicon Nitride and Silicon Carbide by Water: Running in, Wear and Operation of Sliding Bearings," Tribol. Lett., 17 [3] 367-76 (2004).

59. A. Udayakumar, M. Balasubramanian, H. B. Gopala, P. Sampathkumaran, S. Seetharamu, R. Babu, D. Sathiyamoorthy, and G. R. Reddy, "Influence of the Type of Interface on the Tribological Characteristics of ICVI Generated $\mathrm{SiC}_{f} / \mathrm{SiC}$ Composites," Wear, 271 859-65 (2011).

60. U. Dulias and K. H. Z. Gahr, "Investigation of $\mathrm{Al}_{2} \mathrm{O}_{3}$ - and SSiC-Ceramic Under Lubricated, Reciprocating Sliding Contact and Cavitation Erosion," Mater Sci. Eng. Technol., 36 [3-4] 140-47 (2005).

61. S. K. Sharma, B. V. M. Kumar, K. Y. Lim, Y.-W. Kim, and S. K. Nath, "Erosion Behavior of SiC-WC Composites," Ceram. Int., 40 6829-39 (2014).

62. J. J. Kim and S.K. Park, "Solid Particle Erosion of SiC and $\mathrm{SiC}-\mathrm{TiB}_{2}$ Composite Hot-Pressed with $\mathrm{Y}_{2} \mathrm{O}_{3}$," Wear, 222 [2] 114-19 (1998).

63. X. Li, H. Ding, Z. Huang, M. Fang, B. Liu, Y. Liu, X. Wu, and S. Chen, "Solid Particle Erosion-Wear Behavior of $\mathrm{SiC}-\mathrm{Si}_{3} \mathrm{~N}_{4}$ Composite Ceramic at Elevated Temperature," Ceram. Int., 40 16201-7 (2014).

64. B. Wang and A.V. Levy, "Erosion Behavior of SiC FiberSiC Matrix Composites," Wear, 138 125-36 (1990).

65. D. F. Wang, J. H. She, and Z. Y. Ma, "Effect of Microstructure on Erosive Wear Behavior of $\mathrm{SiC}$ Ceramics," Wear, 180 35-41 (1995).

66. J. L. Routbort and A. P. L. Turner, "The Erosion Rate of Reaction-Bonded SiC Containing Various Amounts of Free Silicon," Wear, 84 381-85 (1983).

67. J. L. Routbort, R. O. Scattergood, and A. P. L. Turner, "The Erosion of Reaction-Bonded SiC," Wear, 59 363-75 (1980). 
68. B. Basu and M. Kalin, "Tribology of Ceramics and Composites," pp. 70-100 in Wear Mechanisms, John Wiley \& Sons, Inc., New Jersey, 2011.

69. S. J. Cho, B. J. Hockey, B. R. Lawn, and S. J. Bennison, "Grain-Size and R-Curve Effects in the Abrasive Wear of Alumina," J. Am. Ceram. Soc., 72 [7] 1249-52 (1989).

70. S. J. Cho, C. D. Um, and S. S. Kim, "Wear and Wear Transition Mechanism in Silicon Carbide during Sliding," J. Am. Ceram. Soc., 78 [4] 1076-78 (1995).

71. J. D. O. Barceinas-Sanchez and W. M. Rainforth, "On the Role of Plastic Deformation during the Mild Wear of Alumina," Acta Mater., 46 [18] 6475-83 (1998).

72. V. S. R. Murthy, H. Kobayashi, N. Tamari, S. Tsurekawa, T. Watanabe, and K. Kato, "Effect of Doping Elements on the Friction and Wear Properties of SiC in Unlubricated Sliding Condition," Wear, 257 89-96 (2004).

73. R. K. Iier, The Chemistry of Silica; pp. 40-60, Wiley Inc., New York, 1979.

74. E. Ciudad, O. B. Lopez, A. L. Ortiz, and F. Guiberteau, "Microstructural Effects on the Sliding-Wear Resistance of Pressureless Liquid-Phase-Sintered SiC Under Diesel Fuel," J. Eur. Ceram. Soc., 33 [4] 879-85 (2013).

75. Y. Zhou, K. Hirao, Y. Yamauchi, and S. Kanzaki, "Tribological Properties of Silicon Carbide and Silicon CarbideGraphite Composite Ceramics in Sliding Contact," J. Am. Ceram. Soc., 86 [6] 991-1002 (2003).

76. S. K. Sharma, B. V. M. Kumar, and Y.-W. Kim, "Effect of WC Addition on Sliding Wear Behavior of SiC Ceramics," Ceram. Int., 41 3427-37 (2015).

77. X. Guo, H. Yang, L. Zhang, and X. Zhu, "Sintering Behavior, Microstructure and Mechanical Properties of Silicon Carbide Ceramics Containing Different Nano-TiN Additive," Ceram. Int., 36 161-65 (2010).

78. H. J. Yeom, Y.-W. Kim, and K. J. Kim, "Electrical, Thermal and Mechanical Properties of Silicon Carbide-Silicon Nitride Composites Sintered with Yttria and Scandia," J. Eur. Ceram. Soc., 35 77-86 (2015).

79. J. Llorente, B. R. Manso, P. Miranzo, and M. Belmonte, "Tribological Performance under Dry Sliding Conditions of Graphene/Silicon Carbide Composites," J. Eur. Ceram. Soc., 36 429-35 (2016).

80. X. Yang, X. Liu, L. Wang, H. Zhang, X. Yao, and Z. Huang, "R-Curve Analysis of Solid-Phase-Sintered and Liquid-Phase-Sintered Silicon Carbide Ceramics by Indentation Fracture and Indentation-Strength-in-Bending Methods," Ceram. Int., 42 4011-18 (2016).

81. D. B. Marshall, B. R. Lawn, and A. G. Evans, "Elastic/ Plastic Indentation Damage in Ceramics: the Lateral Crack System,” J. Am. Ceram. Soc., 65 [11] 561-66 (1982)

82. B. R. Lawn, N. P. Padture, F. Guiberteau, and H. Cai, "A Model for Microcrack Initiation and Propagation Beneath Hertzian Contacts in Polycrystalline Ceramics," Acta Metall. Mater., 42 [5] 1683-93 (1994).

83. A. Tewari, B. Basu, and R. K. Bordia, "Model for Fretting Wear of Brittle Ceramics," Acta Mater., 57 2080-87 (2009).

84. S. Gupta, S. K. Sharma, B. V. M. Kumar, and Y.-W. Kim, "Tribological Characteristics of $\mathrm{SiC}$ Ceramics Sintered with a Small Amount of Yttria," Ceram. Int., 41 14780-89
(2015).

85. J. F. Li, J. Q. Huang, S. H. Tan, Z. M. Cheng, and C. X. Ding, "Tribological Properties of Silicon Carbide under Water-Lubricated Sliding," Wear, 218 167-71 (1998).

86. A. Kovalcikova, P. Kurek, J. Balko, J. Dusza, P. Sajgalik, and M. Mihalikova, "Effect of the Counterpart Material on Wear Characteristics of Silicon Carbide Ceramics," Int. J. Refract. Met Hard Mater., 44 12-8 (2014).

87. G. Amirthan and M. Balasubramanian, "Reciprocating Sliding Wear Studies on Si/SiC Ceramic Composites," Wear, 271 1039-49 (2011).

88. V. M. Candelario, O. B. Lopez, F. Guiberteau, R. Morenob, and A. L. Ortiz, "Sliding- Wear Resistance of Liquid-Phase-Sintered SiC Containing Graphite Nanodispersoids," J. Eur. Ceram. Soc., 34 2597-602 (2014).

89. J. Takadoum, Z. Zsiga, and C. Roques-Carmes, "Wear Mechanism of Silicon Carbide: New Observations," Wear, 174 239-42 (1994).

90. L. Micele, G. Palombarini, S. Guicciardi, and L. Silvestroni, "Tribological Behaviour and Wear Resistance of a SiC- $\mathrm{MoSi}_{2}$ Composite Dry Sliding against $\mathrm{Al}_{2} \mathrm{O}_{3}$," Wear, 269 368-75 (2010).

91. R. Wasche, D. Klaffke, and T. Troczynski, "Tribological Performance of $\mathrm{SiC}$ and $\mathrm{TiB}_{2}$ against $\mathrm{SiC}$ and $\mathrm{Al}_{2} \mathrm{O}_{3}$ at Low Sliding Speeds," Wear, 256 695-704 (2004).

92. K. Kato, "Tribology of Ceramics," Wear, 136 117-33 (1990).

93. S. Hotta and Y. Mizutani, "Effect of Water and Organic Solvents on the Friction of SiC," pp. 1-4 in Proceedings, 32nd JSLE, Japanese Society of Lubrication Engineers Conference, Tokyo, Japan (1988).

94. X. F. Chen, X. G. Xu, X. B. Hu, J. Li, S. Z. Jiang, L. N. Ning, Y. M. Wang, and M. H. Jiang, "Anisotropy of Chemical Mechanical Polishing in Silicon Carbide Substrates," Mater. Sci. Eng. B, 142 28-30 (2007).

95. H. Y. Liu and M. E. Fine, "Modeling of Grain-Size Dependent Microfracture-Controlled Sliding Wear in Polycrystalline Alumina," J. Am. Ceram. Soc., 76 [9] 2393-96 (1993).

96. S. J. Cho, H. Moon, B. J. Hockey, and S. M. Hsu, "The Transition from Mild to Severe Wear in Alumina During Sliding," Acta Metall., 40 [1] 185-92 (1992).

97. X. Dong and S. Jahanmir, "Wear Transition Diagram for Silicon Nitride," Wear, 165 169-80 (1993).

98. W. M. Rainforth, "The Wear Behavior of Oxide CeramicsA Review," J. Mater. Sci., 39 [2] 6705-21 (2004).

99. X. Wang, N. P. Padture, H. Tanaka, and A. L. Ortiz, "Wear-Resistant Ultra-Fine-Grained Ceramics," Acta Mater., 53 [2] 271-77 (2005).

100. B. Frisch, W. R. Thiele, R. Drumm, and B. Muennich, "On the Oxidation Mechanism of Silicon Carbide in the $300^{\circ} \mathrm{C}$ to $1300^{\circ} \mathrm{C}$ Temperature Range," Ceram. Forum Int., 65 [8-9] 277-84 (1988).

101. S. C. Singhal, "Thermodynamical Analysis of the HighTemperature Stability of Silicon Nitride and Silicon Carbide," Ceram. Int., 2 [3] 123-30 (1976).

102. P. C. Kong and E. Pfender, "Formation of Ultrafine $\beta$ Silicon Crabide Powders in an Agron Thermal Plasma Jet," Langmuir, 3 [2] 259-65 (1987).

103. Z. Zhu, V. Muratov, and T. E. Fischer, "Tribochemical 
Polishing of Silicon Carbide in Oxidant Solution," Wear, 225-229 848-56 (1999).

104. L. C. Erickson, A. Blomberg, S. Hogmark, and J. Bratthall, "Tribological Characterization of Alumina and Silicon Carbide under Lubricated Sliding," Tribology Int., 26 [2] 83-92 (1993).

105. H. Tomizawa and T. E. Fischer, "Friction and Wear of Silicon Nitride and Silicon Carbide in Water: Hydrodynamic Lubrication at Low Sliding Speed Obtained by Tribochemical Wear," ASLE Trans., 30 [1] 41-6 (1987).

106. J. K. Lancaster, "A Review of the Influence of Environmental Humidity and Water on Friction, Lubrication and Wear," Tribology Int., 23 [6] 371-89 (1990).

107. S. Sasaki, "The Effects of Water on Friction and Wear of Ceramics,” J. Jpn. Soc. Lubr. Eng., 10 10-26 (1988).

108. R. Wasche and D. Klaffke, "Ceramic Particulate Composites in the System $\mathrm{SiC}-\mathrm{TiC}-\mathrm{TiB}_{2}$ Sliding against $\mathrm{SiC}$ and $\mathrm{Al}_{2} \mathrm{O}_{3}$ Under Water," Tribology Int., 32 197-206 (1999).

109. E. Medvedovski, "Ballistic Performance of Armour Ceramics: Part 1. Influence of Design and Structure," Ceram. Int., 36 2103-15 (2010).

110. A. G. Evans and T. R. Wilshaw, "Dynamic Solid Particle Damage in Brittle Materials, An Appraisal," J. Mater. Sci. 12 97-116 (1977).

111. J. G. Chacon-Nava, F. H. Stott, S. D. de la Torre, and A. Martinez-Villafane, "Erosion of $\mathrm{Al}_{2} \mathrm{O}_{3}$ and $\mathrm{SiC}$ at Low Impact Velocities," Mater. Lett., 55 269-73 (2002).

112. J. L. Routbort and R. O. Scattergood, "Anomalous SolidParticle Erosion Rate of Hot Pressed Silicon Carbide," $J$. Am. Ceram. Soc., 63 593-95 (1980).

113. S. M. Wiederhorn and B. J. Hockey, "Effect of Material Parameters on the Erosion Resistance of Brittle Materials," J. Mater. Sci., 18 766-80 (1983).

114. J. L. Routbort and H. Matzke, "On the Correlation Between Erosion and Fracture Parameters in $\mathrm{SiC}$ Ceramics," J. Mater. Sci., 18 1491-96 (1983).

115. D. Jianxin, L. Lili, and D. Mingwei, "Erosion Wear Behaviours of $\mathrm{SiC} /(\mathrm{W}, \mathrm{Ti}) \mathrm{C}$ Laminated Ceramic Nozzles in Dry Sand Blasting Processes," Mater. Sci. Eng. A, 444 120-29 (2007).

116. A. F. Colclough and J. A. Yeomans, "Hard Particle Erosion of Silicon Carbide and Silicon Carbide-Titanium Diboride from Room Temperature to $1000^{\circ} \mathrm{C}$," Wear, 209 229-36 (1997).

117. I. M. Hutchings, "Tribology: Friction and Wear of Engineering Materials; pp. 352, Edward Arnold, London, 1992.

118. J. F. Bell, and P. S. Rogers, "Laboratory Scale Erosion Testing of a Wear Resistant Glass-Ceramic," Mater. Sci. Tech., 3 807-13 (1987).

119. P. Gautier and K. Kato, "Wear Mechanisms of Silicon Nitride Partially Stabilized Zirconia and Alumina in Unlubricated Sliding against Steel," Wear, 162-164 30513 (1993).

120. D. K. Shetty, I. G. Wright, and A. H. Clauer, "Coal Slurry Erosion of Reaction-Bonded SiC," Wear, 79 275-79 (1982).

121. B. Q. Wang and A. V. Levy, "Erosion Behavior of SiC Fiber-SiC Matrix Composites," Wear, 138 125-36 (1990).
122. I. Finnie, J. Wolak, and Y. H. Kabil, "Erosion of Metals by Solid Particles," J. Mater., 2 [3] 682-700 (1967).

123. G. Amirthana, A. Udaya Kumar, V.V. Bhanu Prasad, and M. Balasubramanian, "Solid Particle Erosion Studies on Biomorphic Si/SiC Ceramic Composites," Wear, 268 14552 (2010).

124. A. R. de A. Lopez, J. M. Fernandez, F. M. V. Feria, T. S . Orlova, K. C. Goretta, F. G. Mora, Nan Chen, and J. L. Routbort, "Erosion and Strength Degradation of Biomorphic SiC," J. Eur. Ceram. Soc., 24 861-70 (2004).

125. B. J. Hockey, S. M. Wiederhorn, and H. Johnson, "Erosion of Brittle Materials by Solid Particle Impact," pp. 379-402 in Fracture Mechanics of Ceramics Vol. 3, Ed. by R. C. Bradt, D. P. H. Hasselman, and F. F. Lange, Plenum Press, New York, 1978.

126. B. J. Hockey and B. R. Lawn, "Electron Microscopy of Microcracking about Indentations in Aluminium Oxide and Silicon Carbide," J. Mater. Sci., 10 [8] 1275-84 (1975).

127. S. M. Wiederhorn and B. J. Hockey, "Effect of Material Parameters on the Erosion Resistance of Brittle Materials," J. Mater. Sci., 18 [3] 766-80 (1983).

128. B. R. Lawn, B. J. Hockey, and S. M. Wiederhorn, "Atomically Sharp Cracks in Brittle Solids: An Electron Microscopy Study," J. Mater. Sci., 15 1207-23 (1980).

129. D. C. Evans and J. K. Lancaster, "The Wear of Polymers," pp. 85-139 in Treatise on Materials Science and Technology: Wear, Vol. 13, Academic Press, New York and London, 1979

130. D. B. Marshall, B. R. Lawn, and A. G. Evans, "Elastic/ Plastic Indentation Damage in Ceramics: The Lateral Crack System," J. Am. Ceram. Soc., 65 [11] 561-66 (1982).

131. A. G. Evans, M. E. Gulden, and M. Rosenblatt. "Impact Damage in Brittle Materials in the Elastic-Plastic Response Regime," Proc. of the Royal Society of London, 361 343-65 (1978).

132. D. Wang and Z. Mao, "Microscopic Observations of Wear of Heat-Resistant Ceramics," Wear, 167 [1] 87-9 (1993).

133. M. M. Chaudhri and S. M. Walley, "Damage to Glass Surfaces by the Impact of Small Glass and Steel Spheres," Phil. Mag. A, 37 [2] 153-65 (1978).

134. C. G. Knight, M. V. Swain, and M. M. Chaudhri, "Impact of Small Steel Spheres on Glass Surfaces," J. Mater. Sci., 12 [8] 1573-86 (1977).

135. B. R. Lawn and D. B. Marshall, "Indentation Fracture and Strength Degradation in Ceramics," pp. 205-29 in Fracture Mechanics of Ceramics, Vol. 3, Ed. by R. C. Bradt, D. P. H. Hasselman, and F. F. Lange, Plenum Press, New York, 1978.

136. M. M. Chaudhri, and P. A. Brophy, "Single Particle Impact Damage of Fused Silica." J. Mater. Sci., 15 [2] 345-52 (1980).

137. M. S. Suh, T. Hinoki, and A. Kohyama, "Erosive Wear Mechanism of New SiC/SiC Composites by Solid Particles," Tribol. Lett., 41 503-13 (2011).

138. S. Gochnour, J. D. Bright, D. K. Shett, "Solid Particle Erosion of $\mathrm{SiC}_{-} \mathrm{Al}_{2} \mathrm{OC}$ Ceramics," J. Mater. Sci., 25 322935 (1990).

139. S. Wada and N. Watanabe, "Solid Particle Erosion of Brittle Materials. III. The Interaction with Material 
Properties of Target and That of Impingement Particle on Erosive Wear Mechanism,” J. Ceram. Soc. Jpn., 95 [6] 573-78 (1987).

140. J. J. Kim and S. K. Park, "Solid-Particle Erosion of HotPressed Silicon Carbide and $\mathrm{SiC}_{-} \mathrm{TiB}_{2}$ Composite," J.
Mater. Sci. Lett., 16 821-23 (1997).

141. Z. H. Huang, J. L. Sun, J. X. Wang, and Y. R. Hong, " $\alpha$ Sialon- $\mathrm{Al}_{2} \mathrm{O}_{3}$-SiC Composite Refractories," Key Eng. Mater., 224 275-80 (2012). 